\title{
ENTRE FOTOGRAFIAS ANTIGAS E REDES SOCIAIS: TRAJETÓRIAS DE PESQUISA FOTOGRÁFICA NO INTERIOR DE MINAS GERAIS E DA PARAÍBA.
}

\author{
João Martinho Braga de Mendonça ${ }^{1}$ \\ Dedicado aos amigos e amigas de Caldas, \\ especialmente para Fábio Ottoni, \\ Philomena Ottoni e \\ Olga Landi.
}

\section{Introdução}

Para situar melhor as reflexões desenvolvidas nesse artigo, permitam-me breve retrospecto. Morei por três anos, entre 2003 e 2005, em uma cidade com pouco mais de dez mil habitantes enquanto desenvolvia pesquisa de doutoramento ${ }^{2}$. Numa festa de aniversário desta cidade, por iniciativa de seus organizadores ${ }^{3}$, foi montada uma exposição de fotografias antigas. Esse episódio teve entre outros resultados a digitalização destas fotografias por um dos moradores envolvidos ${ }^{4}$, o que despertou meu interesse no sentido de fazer uma pesquisa que investisse no potencial desse material imagético. Tratei de propor, assim, um aprofundamento do conhecimento das fotografias da exposição no que diz respeito à identificação dos motivos enfocados e à reelaboração dos seus significados e usos possíveis na atualidade, inclusive em termos de sua preservação, junto aos seus guardadores.

Este projeto foi submetido no primeiro edital da organização não governamental "Oportunidade", criada para o desenvolvimento de atividades culturais e de inclusão social. Contou, assim, com o apoio desta ONG em termos da divulgação do trabalho proposto e obteve apoio também do Centro Estadual de Educação Continuada e da Prefeitura Municipal. Esta disponibilizou cópias impressas para uso no projeto e o $\mathrm{CESEC}^{6}$ disponibilizou espaços para as reuniões do grupo de trabalho formado ${ }^{7}$. Dessa maneira teve início pesquisa fotográfica e antropológica que seria interrompida, seis

\footnotetext{
${ }^{1}$ Universidade Federal da Paraíba, Brasil.

2 Refiro-me ao município de Caldas, localizado no planalto da Pedra Branca, ao sul de Minas Gerais. Caldas foi fundada em 1813 (como Freguesia) e decretada cidade em 1859. Fica a cerca de 2 hs de Campinas-SP.

${ }^{3}$ Do Conselho do Patrimônio Histórico e Cultural, da Câmara de Vereadores e do Centro Estadual de Estudos Continuados.

${ }^{4}$ Fábio Ottoni, cuja colaboração se fez presente inclusive neste artigo, como será visto adiante.

${ }^{5}$ Entidade que se mantém principalmente através de contribuições mensais de seus associados.

${ }^{6}$ Através de sua vice-diretora Suely Landi Guimarães Lemes.

${ }^{7}$ Por membros das famílias que emprestaram as fotografias à exposição e outros interessados.
} 
meses depois, quando ingressei como professor na área de antropologia da Universidade Federal de Campina Grande, no estado da Paraíba, onde moro há pelo menos cinco anos.

Em Campina Grande, como docente, desenvolvi outros trabalhos de pesquisa e mantive alguma correspondência com o principal colaborador desta pesquisa em Caldas, sem deixar de vislumbrar a continuidade do projeto. Fiz um breve relato oral sobre a pesquisa numa comunicação que apresentei na VII Semana de Ensino, Pesquisa e Extensão do Centro de Humanidades da UFCG e eventualmente utilizei algumas fotografias antigas dos acervos de Caldas para trabalhar com alunos, em sala de aula, aspectos técnicos das imagens fotográficas antigas. Com a distância e as novas exigências da docência, não me foi possível acompanhar de perto o projeto iniciado em Caldas. Manteve-se, contudo, o interesse de alguns moradores pela pesquisa da fotografia antiga, em especial de Fábio Ottoni, que passou a coordenar, juntamente com Olga Landi, o pequeno grupo de trabalho que havíamos reunido em torno das imagens antigas $^{8}$.

Depois de três anos em Campina Grande reingressei como docente, desta vez para a área específica de "antropologia visual”, num curso de graduação em antropologia recém aberto pela Universidade Federal da Paraíba, no município de Rio Tinto. Esta outra mudança me levou a reencontrar o interesse pelas fotografias antigas em pequenas cidades. De modo semelhante como a Caldas, dois anos depois em Rio Tinto foi organizada uma exposição fotográfica por ocasião do aniversário da cidade (em 2006), com fotografias antigas oriundas de diversas famílias, reunidas e digitalizadas por um de seus moradores. Essa exposição é hoje um dos temas da pesquisa que desenvolvo com o apoio do $\mathrm{CNPq}^{9}$, a qual inclui parceria com o BIEV e o NAVISUAL (ambos da UFRGS ${ }^{10}$ ).

\footnotetext{
${ }^{8}$ Esse trabalho persistiu até 2008 e seus resultados encontram-se hoje arquivados. Outro trabalho com o mesmo tipo de fotografias, desenvolvido paralelamente na mesma época e de forma independente por Fábio Ottoni teve seguimento e foi concluído em 2009, consiste numa edição de duzentas imagens fotográficas antigas acompanhadas de informações históricas (Ottoni, 2009).

${ }^{9}$ Projeto "Município de Rio Tinto e T.I. Potiguara: explorações iniciais de Antropologia Visual" (Edital CNPq/MCT 03/2009).

${ }^{10}$ A Universidade Federal do Rio Grande do Sul (UFRGS) abriga o Banco de Imagens e Efeitos Visuais (BIEV) e o Núcleo de Antropologia Visual (NAVISUAL). Esta parceria permitiu que, em 2011, fosse oferecido em Rio Tinto-PB o "I Seminário de Antropologia Visual - Percepção, conhecimento, produção e criação de memórias coletivas através da imagem e do som", ministrado pelas Profas. Cornélia Eckert e Ana Luiza Carvalho da Rocha.
} 
Foi nesse contexto, portanto, que esse artigo surgiu, como um modo de contribuir à reflexão sobre imagens e outros temas pertinentes a partir de relatos das experiências de pesquisa referidas acima e das questões por elas suscitadas.

\section{Fotografias de Caldas: memória, diálogo e reflexão}

A pesquisa fotográfica em Caldas teve como ponto de partida um conjunto de 142 imagens em preto e branco, oriundas de 15 acervos de família ${ }^{11}$. Os guardadores destas imagens são pessoas das famílias locais que habitam a região há pelo menos duas gerações. Fui convidado, em março de 2004, para colaborar com a referida exposição fotográfica comemorativa, quando então tomei contato com as imagens e pessoas envolvidas em sua organização. Dessa maneira, a relação estabelecida posteriormente na pesquisa era entre moradores da cidade que apostavam, de alguma forma, no valor das fotografias antigas. Moradores mais antigos, que projetam ali memórias das suas famílias, e um morador mais recente, que ali residia há mais de um ano e que pesquisava fotografias etnográficas, com interesse em pesquisar as fotografias históricas locais.

Evidentemente que o grande desafio seria conciliar não só a participação dos diferentes moradores locais, suas preocupações e motivações, como também os interesses de pesquisa em antropologia visual, para além da identificação dos cenários e personagens locais. Como trabalhava, na época, em torno da análise fotográfica elaborada por Gregory Bateson para o livro publicado com Margaret Mead (Bateson e Mead, 1942) sobre o caráter dos moradores da ilha de Bali, vislumbrei a possibilidade de elaborar, com as fotografias históricas locais, "composições verbais-visuais"12 que poderiam tanto servir à pesquisa sobre a cultura (ou ethos) caldense como para posterior publicação de seus resultados de maneira a fazer intervir na cultura local novas perspectivas sobre as cenas passadas e consequentemente sobre o futuro do município.

Havia também de minha parte alguma preocupação com o sentido colaborativo (Banks, 1995: 3) da pesquisa com imagens em antropologia, de maneira que os sujeitos da pesquisa pudessem participar continuamente da elaboração dos conhecimentos

\footnotetext{
${ }^{11}$ Esses números dizem respeito ao material que me foi disponibilizado pelo CESEC, aproximadamente o mesmo que foi exposto no aniversário da cidade em 2004; o pesquisador Fábio Ottoni, contudo, mantém informações mais precisas sobre o número de fotografias expostas nesta ocasião.

12 Essa expressão foi escolhida pelo orientador da pesquisa, Prof. Etienne Samain, e busca traduzir o sentido da reflexões metodológicas e epistemológicas que desenvolvi para a tese de doutoramento sobre Margaret Mead, particularmente no capítulo 3 (Mendonça, 2005: 177-229).
} 
produzidos. Os modelos de análise fotográfica (Bateson e Mead, 1942: 55-255) ${ }^{13}$ que me serviam de ponto de partida, entretanto, haviam sido publicados em 1942 com base em pesquisas etnográficas realizadas em contextos coloniais, nos quais os cientistas eram financiados por determinado tempo nos territórios colonizados e depois voltavam ao seu país de origem (Europa ou EUA). Esse tipo de contexto de pesquisa é predominante na história desta disciplina.

O contexto da pesquisa fotográfica em Caldas, no entanto, era diferente. Embora não fosse natural de Caldas, havia me tornado seu habitante e me via realizado em estabelecer compromissos com moradores mais antigos em torno de um trabalho com fotografias. Podia sentir que o projeto havia de colaborar para a cidadania e a cultura locais e que minha participação nesse processo tinha alguma chance de ser duradoura. Além disso, tomava parte num grupo de amigos e conhecidos que se reunia com alguma frequência para discutir temas de economia solidária e de cultura emancipatória ${ }^{14}$, o que incitava ainda mais o sentido colaborativo pretendido.

Foi nessa atmosfera que formulei os objetivos do projeto $^{15}$ apresentado à ONG "Oportunidade", a saber:

1. Trabalhar com a memória fotográfica da cidade junto à população idosa, no sentido de promover sua importância como cidadãos ativos e necessários à produção de conhecimentos;

2. Propiciar a todos os participantes oportunidades de diálogo, rememoração e reflexão com imagens, através da constituição de grupos e equipes de trabalho;

3. Classificar, descrever e interpretar o "corpus" de fotografias relativas da exposição do aniversário da cidade em 2004;

A fase inicial desse trabalho teve por referência principal as obras de Boris Kossoy sobre a fotografia histórica, particularmente o livro Fotografia e história (Kossoy, 2001), que além de fornecer orientações práticas para a pesquisa (tais como indicações de fontes, modelos para recuperação de informações fotográficas, etc.), se mostrava

\footnotetext{
${ }^{13}$ A análise fotográfica feita por Gregory Bateson pode também ser pensada em termos de "dezenas de modelos de apresentação de suas fotografias" (Samain, 2004: 55).

${ }^{14} \mathrm{O}$ sítio Rosa dos Ventos em Caldas é um espaço de acolhimento dirigido pelo professor Carlos Rodrigues Brandão, um exemplo recente das atividades aí desenvolvidas está disponível em: $<\mathrm{http}: / /$ cirandas.net/rede-de-formadores-em-economia-solidaria-sudeste/curso-regional-de-formacao-deeducadores-as-em-economia-solidaria-\%E2\%80\%93-regiao-sudeste>. Acesso em: 01 nov2011.

${ }^{15}$ Os quais esperava desenvolver posteriormente com algum tipo de financiamento acadêmico obtido junto à Universidade Estadual de Campinas (Unicamp).
} 
mais acessível e com sentidos mais aproximados das expectativas dos caldenses em torno às fotografias antigas ${ }^{16}$. Assim, a reconstituição das cenas passadas, as rememorações pelos habitantes mais antigos, a duração de certos costumes, tudo isso figurava como campo de possíveis desdobramentos do trabalho proposto.

O desenvolvimento desse tipo de resultados deveria, na concepção esboçada para o projeto, levar a um segundo momento onde fosse possível discutir os problemas atuais da cidade junto aos moradores (não apenas idosos) através do conhecimento fotográfico produzido. Tratava-se de apostar na fotografia como uma forma de conhecimento que poderia servir, inclusive, às políticas públicas do município, sobretudo no tocante à inclusão social, educação e conscientização acerca de diversos aspectos (meio ambiente, economia, esporte, turismo, lazer, arte, etc.).

Uma fotografia, por exemplo, de um passeio dominical no campo pode servir como exemplo dessa hipótese de trabalho.

\section{Fotografia 1: Piquenique dominical ${ }^{17}$}

Trata-se de uma cena de piquenique na qual aparecem diversas personagens sentadas em roda em meio a um bosque. A moradora que guarda esta fotografia ${ }^{18}$ informou alguns detalhes sobre a cena que lhe é inteiramente familiar. Primeiramente o local foi identificado, chamado "Coqueirinho", logo no início da estrada que dá acesso à Pedra do Coração (um dos pontos turísticos e símbolo da cidade). A data aproximada foi situada nos anos trinta ${ }^{19}$. O grupo é formado por duas irmãs (mãe e tia), outro tio, primos e amigos; dos nove sujeitos que aparecem, cinco foram identificados pelo nome completo. Foi também apontado o provável conteúdo dos cestos: "virado de frango", "quitanda" (variados biscoitos caseiros), "vinho e pão recheado".

\footnotetext{
${ }^{16}$ A outra obra a que me referi (Bateson e Mead, 1942) e que guiava as possibilidades futuras do projeto, além de trazer fotografias de uma cultura muito distante como a balinesa (Indonésia), não foi ainda traduzida ao português, fatores que dificultavam em certa medida o acesso dos caldenses a este material de fundamental importância no campo da antropologia visual.

17 Todas as fotografias apresentadas ao longo deste artigo tiveram seu tamanho original alterado de maneira a ajustarem-se à diagramação do artigo e em função do grau de definição (maior ou menor) obtido devido a diferentes condições de digitalização.

${ }^{18}$ A Sra. Philomena Araujo Ridolfi Ottoni guarda várias fotografias e coleciona objetos antigos, prestounos diversas informações sobre o grupo de fotografias que cedeu para a exposição comemorativa do aniversário da cidade. Agradecemos por sua colaboração, apoio e amizade. As informações a seguir nos foram por ela confiadas na tarde do dia 26out2005, quando a visitamos em sua casa, vizinha à nossa. Essa sessão de rememoração foi realizada junto com Klara Schenkel, de cuja colaboração sou também devedor.

${ }^{19}$ Essa estimativa sobre a data baseia-se na familiaridade com os personagens enfocados, estima-se pela foto a idade provável da personagem naquela cena, o que é cotejado então com a data de nascimento previamente conhecida.
} 


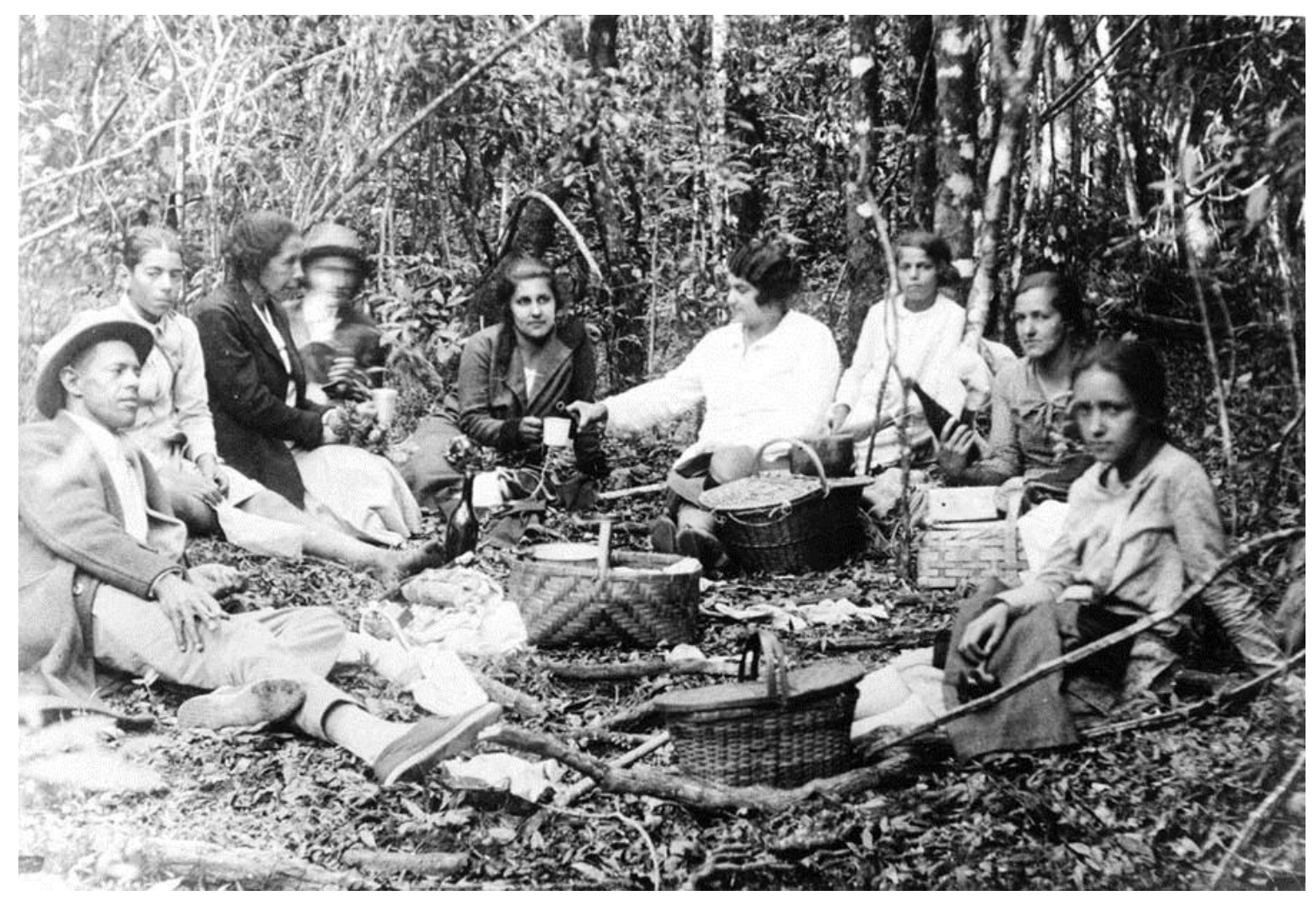

Fotografia 1: autor não identificado/ Acervo de Philomena Ottoni - década de 30[?]

O relato de Philomena Ottoni esclareceu que o costume era ir ao piquenique todos os domingos, após a Missa. Notou também o galho de flor no colo de sua mãe, o que lhe indicava o fato de serem muito românticas e gostarem de se "enfeitar com flores". Uma seqüência possível da pesquisa com esta imagem (e com outras tomadas no mesmo dia) seria buscar mais imagens e informações com descendentes daqueles que foram reconhecidos nesta cena ${ }^{20}$. Esse exercício permitiria não apenas refinar as identificações e preencher lacunas, mas também obter opiniões de perspectivas diversas acerca do assunto e da fotografia.

Essa rememoração da cena passada pelos sujeitos enfocados, além disso, freqüentemente traz à tona reflexões e juízos sobre o tempo atual, o que acrescenta uma dimensão a mais na pesquisa fotográfica, na medida em que entra em jogo quase sempre a preocupação com o presente e o futuro da cidade. Porém, antes de abordar o potencial da fotografia antiga para a atualidade, algumas considerações serão apresentadas sobre outras dimensões da pesquisa.

\footnotetext{
${ }^{20}$ Inclusive dados sobre como seu deu a situação da pose e até que ponto alguns gestos (com as garrafas) foram planejados (ou não) para a foto.
} 


\section{Aspectos tecnológicos}

O aspecto tecnológico da pesquisa fotográfica também precisa ser notado. Tratase, por exemplo, de examinar o original mais antigo para buscar pistas sobre o tipo de câmera e de processos envolvidos na sua produção. Na fotografia do piquenique o artefato fotográfico original possui tamanho de $9 \times 13 \mathrm{~cm}$. Não tivemos informações sobre seu autor. Para a exposição foi feita uma ampliação em tamanho 20 x $25 \mathrm{~cm}$. Nota-se que o rosto da quarta pessoa da esquerda para a direita encontra-se desfocado, o que se deve ao rápido movimento da cabeça no momento da tomada da foto. Esse fator indica que a velocidade de obturação da câmera operou num intervalo específico (em velocidade baixa, menor que $1 / 60$ de segundo).

Estas poucas informações, no entanto, uma vez armazenadas e cotejadas progressivamente com outras, são suficientes para futuras descobertas, seja em relação à câmera e aos processos utilizados, ao autor da fotografia, à época e até aos elementos da cena. É possível descobrir quais os tipos de câmera ${ }^{21}$ que funcionavam com velocidades baixas de obturação (fator técnico que pressupõe a imobilidade da pose). Além disso, se toda fotografia é produzida dentro de uma série, o que diz respeito tanto ao tipo de película ou de papel fotográfico vindos de fábrica, mas também ao processo de ampliação e aos tipos de formatos, sinais, recortes e bordas utilizadas pelo fotógrafo, é possível ainda encontrar trabalhos do mesmo autor ou da mesma época, na medida em que imagens de acervos familiares diversos podem ser cotejadas e identificadas.

Os dados relativos à câmera e aos papéis e tecnologias utilizadas levam pelo menos a dois tipos de conhecimento. Do autor das imagens, que por seus familiares ou por seus trabalhos pode indicar um percurso pelo qual o aprendizado e a prática fotográfica se fizeram presentes numa cidade, de forma fixa ou itinerante e geralmente relacionada ao trânsito da cidade menor para outra maior mais próxima, onde materiais fotográficos podiam ser adquiridos e novas técnicas aprendidas. Conhecimento também da época em que a fotografia foi tomada, seja para confirmar ou tornar mais precisa uma estimativa já existente com base em outras informações (caso da fotografia do piquenique), seja para estabelecer uma estimativa quando não houver nenhuma outra base de onde partir. Neste último caso a época da tomada é estimada principalmente

\footnotetext{
${ }^{21}$ Para diferentes modelos de câmera há registros do primeiro ano de sua fabricação até o ano em que saiu de linha (dados que podem ser obtidos junto ao fabricante ou com colecionadores, muitas vezes disponíveis na internet).
} 
pela possibilidade de determinação do período de uso da tecnologia empregada (tipo de papel e/ou câmera) a partir de registros do comércio fotográfico e da história de suas tecnologias.

\section{Apontamentos analíticos}

Outros apontamentos podem ser oferecidos, desta vez, em relação às possibilidades de análise de fotografias. A noção de seriação na pesquisa fotográfica ${ }^{22}$ merece especial atenção, as séries podem ser estabelecidas "de acordo com o problema estudado" (Leite, 1992: 34) e são importantes também ao nível da própria organização dos acervos. Por outro lado, sobretudo na elaboração para apresentação pública (seja com intenções artísticas, científicas ou ambas) “(...) a seriação e correlação de imagens compõem a mensagem da fotografia (...)" (Leite, 1992: 47). Um exemplo de análise e apresentação de fotografias em séries pode ser encontrado no livro Carnaval em branco e negro (Simson, 2007).

Noto nesta mesma direção que a idéia de "composição verbal-visual" (Mendonça, 2005: 252), referida anteriormente, partiu da "análise fotográfica" experimentada por Gregory Bateson em fins dos anos 30 e publicada em 1942 (Bateson e Mead, 1942) tanto quanto da reflexão em termos dos "modelos de apresentação" das fotografias, em que possibilidades de "combinação de elementos sígnicos" permitem reconhecer, no trabalho de Bateson, dois tipos de modelos: "seqüencial e estrutural" (Samain, 2004: 56-58) ${ }^{23}$. Esta linha de reflexão ${ }^{24}$ permanece, ao meu ver, como base operacional na constituição de um conhecimento fotográfico que tenha como centro as próprias imagens e suas possíveis inter-conexões.

\section{A fotografia antiga e seus usos na atualidade}

Mas como os descendentes das personagens que aparecem na fotografia 1 avaliam o passado e o presente a partir desta cena fotografada? Como o conhecimento da cena passada de um piquenique contribui para a resolução de problemas atuais da cidade? Práticas de lazer no passado podem ajudar ao entendimento do presente? Questões como essas se colocam como desafio à pesquisa fotográfica local. Não caberá

\footnotetext{
${ }^{22}$ Que não se deve confundir simplesmente com o que pode ser deduzido a partir de marcas ou números de série de materiais fotográficos.

${ }^{23}$ Ver também a distinção entre "série" e "seqüência" referida em BECKER (2009: 48) junto à reflexão que propõe sobre o trabalho fotográfico de Walker Evans nos EUA.

${ }^{24}$ Espero retomar e discutir mais extensamente estes apontamentos em outro artigo.
} 
aqui estendê-las, mas apenas esboçar elementos para pensar uma (entre outras) utilização possível da fotografia antiga na atualidade.

Se a bebida (vinho) e a comida (frango, biscoitos e pães) nos dão uma pista da economia caldense (cultivo de extensos parreirais, criação de gado leiteiro e de galinhas, etc.), a forma como são transportadas em cestos e garrafas de vidro não deixa dúvidas sobre como antigos hábitos de consumo eram diferentes dos atuais. Ora, um dos problemas locais enfrentados hoje na cidade diz respeito ao lixo (plástico, latas, etc.) deixado nas cachoeiras e trilhas (onde circula muita gente aos domingos e feriados) e, de modo mais geral, à questão da preservação ambiental, ameaçada também pela prática predatória de mineração ${ }^{25}$.

O trabalho com as fotografias antigas, neste caso, teria a função de tornar mais sensível (e explícito) o problema para os moradores, sobretudo para as crianças, para quem materiais didáticos elaborados com imagens pesquisadas poderiam ser oferecidos. Seria preciso constituir, a partir da cena do piquenique, uma série inteira de imagens que pudessem trazer à tona aspectos problemáticos da ocupação humana na cidade.

A título de comparação outras fotografias poderiam ser produzidas para alimentar o conhecimento obtido, numa espécie de educação (e conscientização) ambiental. Tratar-se-ia de propiciar uma visão abrangente das formas de ocupação humana que tiveram e tem lugar na cidade, para motivar a reflexão sobre os hábitos atuais e as decisões futuras. A identificação e análise das séries reunidas (antigas e atuais) serviria, então, de base para as composições finais (apresentações públicas em vários formatos possíveis).

A elaboração de fotografias antigas nessa direção coloca a possibilidade de que o conhecimento seja efetivamente visto e percebido nas imagens pesquisadas. Um material didático produzido neste sentido teria que apostar em estratégias de editoração e de uso de imagens onde as mesmas seriam alçadas à condição de veículos analíticos, descritivos ou narrativos.

Ao contrário daquilo que é mais comum e propagado no que toca ao uso de imagens na comunicação social: a fotografia como ilustração complementar de um conhecimento (ou notícia) que é apresentado e verbalizado ao longo de um texto. A proposta de conhecimento fotográfico implica, pelo contrário, em usar a textualização

\footnotetext{
${ }^{25}$ Caldas é destino de turismo e lazer no sul de Minas, com suas águas medicinais descobertas no século XIX, abriga um Balneário no seu distrito de Pocinhos do Rio Verde, onde fica também o "Grande Hotel", que se conta como o mais antigo em funcionamento ininterrupto no Brasil.
} 
ou a verbalização de forma auxiliar e tangencial às disposições imagéticas (de um grupo de fotografias), experimentadas como elementos centrais e definidores dos conteúdos das mensagens.

\section{Fotografia 2: Um time de futebol de Ipuiúna}

Outra fotografia do acervo de Philomena Ottoni pode nos levar a outras reflexões e possibilidades de pesquisa. Trata-se de uma imagem posada de um time de futebol. Neste caso, ressalto inicialmente o aspecto itinerante da fotografia. Tanto os fotógrafos perfazem viagens e mudam-se com alguma frequiência, sobretudo quando se trata de buscar clientela, quanto também as próprias fotografias e os seus portadores viajam (ou mudam-se) pelas mais diversas razões.

A fotografia a seguir foi obtida junto a um morador da cidade vizinha (Santa Rita de Caldas $^{26}$ ), provavelmente também colecionador de objetos antigos com quem a atual guardadora da imagem travou contato (a partir de sua rede de parentesco). Se no primeiro caso, contudo, a fotografia era inteiramente familiar e permitia identificações de personagens, cenários, etc., desta vez trata-se mais propriamente de um artefato colecionado, aparentemente sem vinculação direta com as histórias familiares de sua guardadora.

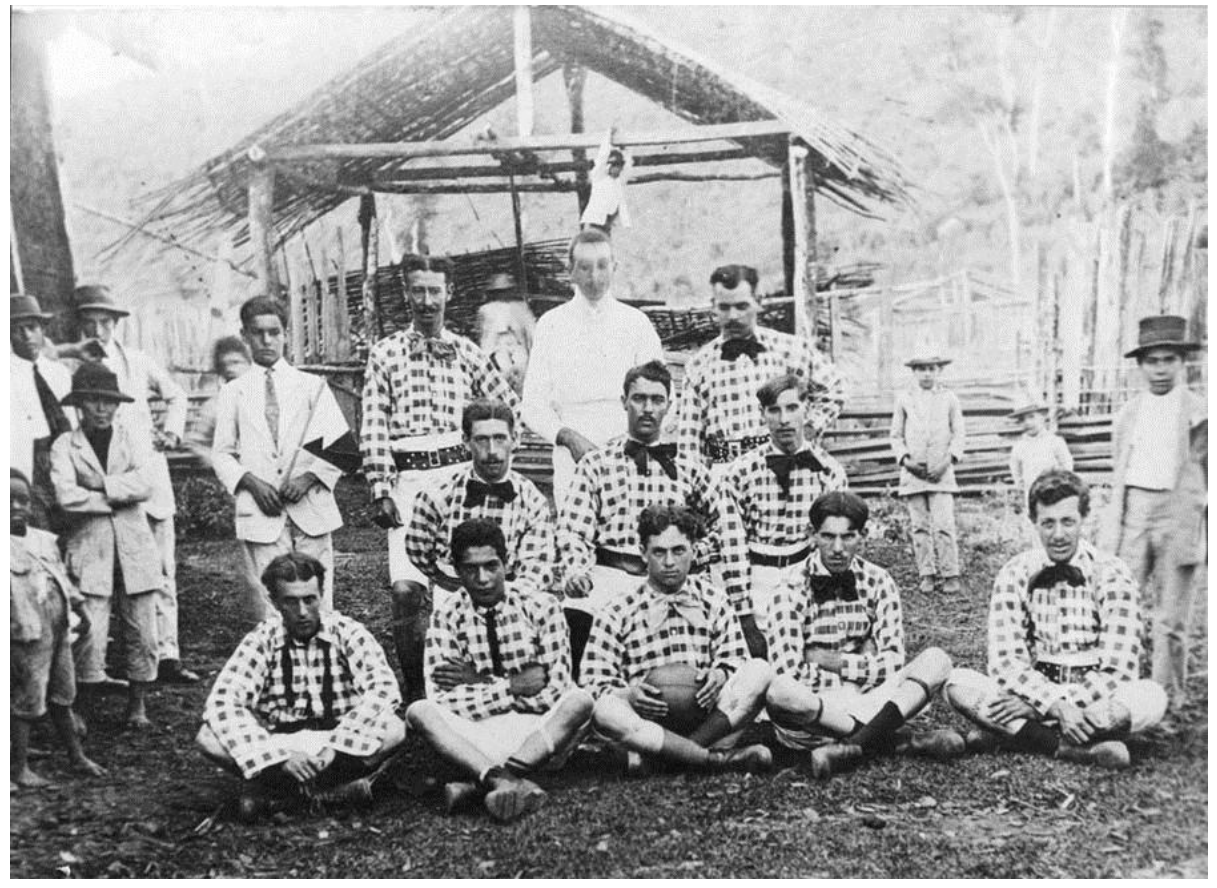

Fotografia 2: autor não identificado/ Acervo de Philomena Ottoni - década de 30[?]

\footnotetext{
${ }^{26}$ Uma das cidades que desmembrou-se de Caldas, fica a uma distância de $18 \mathrm{Km}$.
} 
A falta de maiores informações, neste caso, torna a cena tanto mais interessante quanto enigmática. Tudo que se pôde saber, até aqui ${ }^{27}$, é que se tratava de um time de futebol de Ipuiúna ${ }^{28}$ e que havia gente de Caldas que jogava nesse time. Porque uma fotografia como esta foi poupada do desaparecimento? Quem a teria produzido? Quem teria chamado o fotógrafo? Por quantas mãos teria passado até chegar ao seu atual destino? Haverá outras cópias espalhadas?

Que dizer da notável indumentária dos atletas? E dos chapéus usados por adultos e crianças? Seria também um Domingo? O desfoque evidente no rosto de três personagens (este vestido todo de branco e outros dois, atrás e ao fundo) nos dá pistas sobre a velocidade de obturação utilizada e, consequientemente, do tipo de câmera e da sua época provável, na primeira metade do século. O contraste entre os que se mexeram (desfocados) e os que estão imóveis indicam, por sua vez, o acontecimento da pose, evidente no modo como os jogadores e os demais presentes à foto olham fixamente para a câmera, devidamente vestidos e contidos em suas posturas padronizadas.

Pode-se perguntar, então, em quê uma série extensa de fotografias antigas (e atuais) cujo assunto seja o futebol poderia nos ajudar a ver e a pensar sobre esse esporte hoje tão popular na região? Em que imagens como esta ajudam a esclarecer a duração dessa prática esportiva introduzida no Brasil no século XIX e as diferentes maneiras pelas quais propicia, em toda parte, formas de sociabilidade bem como expressões de conflitos e tensões?

No caso de haver apenas esta fotografia (e não uma série) outras fontes (como jornais da época) poderiam atenuar nosso desconhecimento da cena, mas é a possibilidade de encontrar outros sujeitos, direta ou indiretamente implicados pela imagem, que nos daria acesso aos seus possíveis significados. Encontro com outros sujeitos não só porque foi uma pose coletiva (com pelo menos 19 pessoas, afora as desfocadas) numa situação socialmente ritualizada, mas também porque cada sujeito que pudesse ser identificado e que falasse à foto (tendo a mesma diante de si) daria apenas um sentido parcial aos vários elementos presentes na cena.

Neste caso, a metodologia de pesquisa proposta não pode estabelecer uma única verdade sobre a cena fotografada. Tampouco seria a fotografia isolada um enigma que pudesse ser decifrado de uma vez por todas. Trata-se, antes, de estabelecer relações mais detidas entre as falas dos sujeitos e os múltiplos elementos das imagens que lhes

\footnotetext{
${ }^{27}$ Com Philomena Ottoni.

${ }^{28}$ Outra cidade vizinha, depois de Santa Rita de Caldas.
} 
dizem respeito, o que pode levar cada cena fotografada a tornar-se uma constelação pulsante de informações (identificações, rememorações, juízos, etc.), correlacionáveis ainda a muitas outras cenas.

Ao longo deste processo, com base nas perspectivas analíticas apontadas mais atrás, o conhecimento fotográfico permitiria criar ou impulsionar formas de sociabilidade reflexivas com outros desdobramentos possíveis. Um dos quais, na medida da apropriação das fotografias históricas por um pequeno grupo, poderia resultar na produção de um filme que expusesse as reflexões motivadas pelas antigas imagens. Não foi outro o sentido desejado para o trabalho que iniciamos em Caldas entre novembro e dezembro de 2005 , em grupos de trabalho que contaram com três a dez participantes. Estas reuniões ocorreram uma vez por semana entre 19:30 e 22:00 e representaram, ao meu ver, uma forma de sociabilidade voltada à rememoração e à reflexão, a qual teve continuidade nos anos seguintes ${ }^{29}$.

Ao considerar, desta vez, a rede mundial de computadores e o modo como uma fotografia é postada numa rede social (ou num blog ou num sítio, etc.) ${ }^{30}$ e largamente comentada, outras possibilidades se abrem à pesquisa. Carregar fotografias de pesquisa para um sítio eletrônico onde possam ser visitadas e comentadas, segundo percursos escolhidos por quem navega de acordo com seus próprios interesses é uma possibilidade que tem sido experimentada no campo da antropologia (Eckert e Rocha, 2001, 2006) (Achutti e Hassen, 2004). Embora esse caminho se some e crie novas perspectivas à pesquisa fotográfica e antropológica ${ }^{31}$, não necessariamente substitui o trabalho presencial que pode ser feito junto às pessoas de faixa etária mais avançada (algumas situadas economicamente nas faixas de renda mais baixas) que ou não tem acesso facilitado aos computadores ou preferem mesmo não interagir com essas máquinas por razões pessoais variadas ${ }^{32}$.

\footnotetext{
${ }^{29}$ Estas reuniões continuaram, com grupos cada vez menores, até 2008, segundo comunicação pessoal de Fábio Ottoni. Estimo que numerosas informações foram agregadas às imagens ao longo desse tempo.

${ }^{30}$ Enquanto finalizava a redação deste artigo encontrei um site de Ipuiúna com uma sessão de "Fotografias antigas" (19 imagens, duas delas mostram equipes esportivas uniformizadas). Disponível em: <http://www.ipuiuna.com.br/fotos-mainmenu-38/fotos-antigas-mainmenu-37>. Acesso em 12 nov2011.

${ }^{31}$ Luiz Achutti, por exemplo, propõe um "caderno de campo virtual" como uma "forma a mais de restituição ao grupo pesquisado" (Achutti e Hassen, 2004: 288). Refere-se ao trabalho desenvolvido na Vila de Itapuã-RS. Disponível em: 〈http://www6.ufrgs.br/fotoetnografia/caderno_campo/index.htm>. Acesso em: 01nov2011.

${ }^{32}$ Razões que merecem atenção e estudos. Pesquisar melhor o uso de fotografias antigas na rede mundial de computadores (em redes sociais, sites, blogs, etc.) permitiria levantar ainda outras questões no tocante às transformações ocorridas no "tempo do virtual" quando as imagens “(...) encarnam-se abstratamente, poderíamos dizer, em modelos matemáticos e em programas informáticos. (...)” (QUÉAU, 1993: 91).
} 
De qualquer modo, o conjunto das possibilidades já apontadas indica que diferentes estratégias podem ser combinadas no trabalho antropológico com fotografias antigas.

\section{Colaboração e pesquisa à distância}

O uso de algumas fotografias neste artigo, destinado à revista eletrônica, por sua vez, não deixa de constituir uma retomada do projeto arquivado, na medida em que o contato (por correio convencional e, depois, por correio eletrônico) com Fábio Ottoni do município de Caldas se fez eticamente necessário desde o início de sua preparação. Através desta colaboração foi possível fazer chegar aos guardadores das imagens originais reproduzidas aqui, as intenções quanto ao uso das imagens e a natureza da publicação pretendida (artigo acadêmico). Colaboração especialmente generosa na medida em que incluiu também a coleta local de informações sobre as duas fotografias a seguir $^{33}$.

A retomada das fotografias de Caldas aqui, contudo, se coloca já num outro horizonte e à distância. Mesmo que o projeto inicial tenha sido suspenso sem concretizar sua busca por seriações e composições, suas imagens e a experiência vivenciada não deixarão de fomentar outros olhares, de perto e de longe. O artigo eletrônico se abrirá, neste sentido, para novos contatos e reflexões de moradores (e exmoradores) que puderem acessar a rede mundial de computadores. Espera-se, efetivamente, que possa servir de contribuição à valorização da fotografia antiga, de seus guardadores locais e de outras pesquisas, contatos e publicações ${ }^{34}$.

As próximas duas fotografias ( 3 e 4 ) apresentadas serão dispostas junto ao texto que foi preparado especialmente como contribuição para este artigo, pelas mãos de Fábio Ottoni em Caldas-MG. Depois de selecioná-las (dentro de um grupo de fotografias que fiz reproduzir ${ }^{35}$ e que não tomou parte na exposição) enviei-as (como também as fotografias 1 e 2) para ele por correio eletrônico em 16 de maio de 2011, com vistas ao consentimento específico para esta publicação. Elas servirão de base para diversas considerações e trazem um pouco do cuidado, da emoção e do interesse vivo pela fotografia antiga sem os quais o trabalho de pesquisa fotográfica dificilmente pode

\footnotetext{
${ }^{33}$ Neste caso as imagens não tomaram parte da exposição de 2004 e não havia informações coletadas sobre elas (estas fotografias foram agregadas ao projeto num segundo momento, em 2005).

${ }^{34}$ Como o já referido livro de Fábio Ottoni (Ottoni, 2009).

35 Estes artefatos originais foram devolvidos ao Paulo Afonso depois que efetuei as reproduções em máquina xerográfica. Isto ocorreu em 2005.
} 
avançar no sentido proposto aqui. Transcrevo, assim ${ }^{36}$, a íntegra das informações por ele coletadas e organizadas junto das imagens cedidas por Paulo Afonso dos Santos Guimarães ${ }^{37}$.

\section{Fotografia 3: Faustino e Esperança}

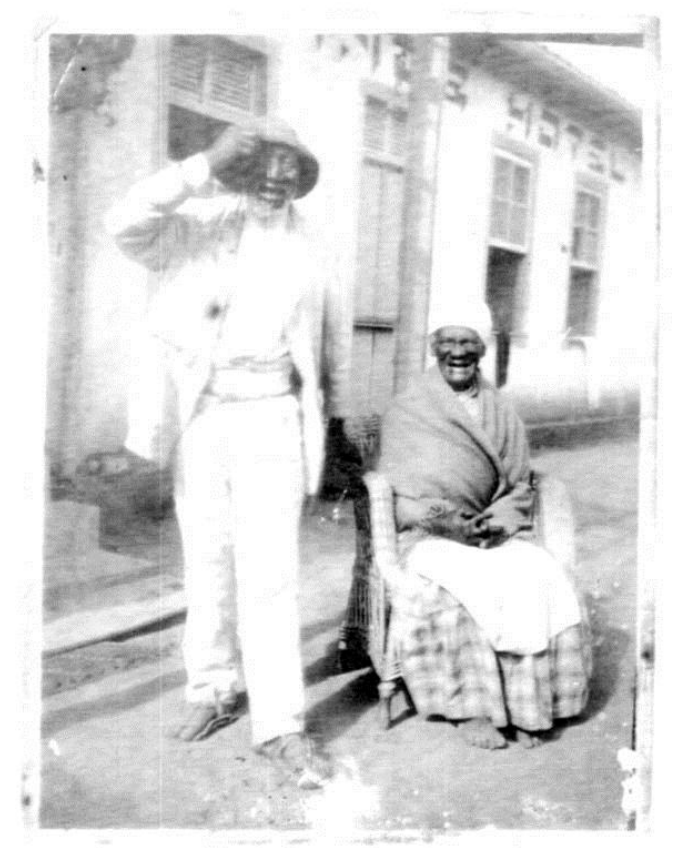

Fotografia 3: autor não identificado/ Acervo de Paulo Guimarães - 1921.

\section{Foto: "Hotel Pocinhos"}

Data: Abril de 1921 (conforme anotação no verso da foto)

Local: Pocinhos do Rio Verde, estância balneária de Caldas - MG.

Cenário: Ao fundo a fachada frontal do Grande Hotel.

Pessoas: Tia Esperança e seu esposo Tio Faustino. Estas duas pessoas eram bastante populares entre seus contemporâneos caldenses. Foram escravos, e também presenciaram muitos fatos históricos de nossa velha Caldas no século XIX. Principalmente Tia Esperança. Já no século XX, ela foi por diversas vezes citada em jornais antigos como fonte de muitas informações e fatos sobre a cidade. Tida como centenária Tia Esperança, já em idade avançada, alimentou com sua lucidez a curiosidade de historiadores caldenses, fornecendo a eles fartas informações. ${ }^{38}$

\footnotetext{
${ }^{36}$ Usarei linhas horizontais acima e abaixo para delimitar os dois conjuntos de informações coletadas e organizadas por Fábio Ottoni (relativos às fotografias 3 e 4), a quem sou grato por compartilhar este material. Acrescentei apenas uma legenda logo abaixo da fotografia.

${ }^{37}$ Agradeço ao músico Paulo Guimarães (Piu) pelo consentimento e as informações prestadas.

${ }^{38}$ Estas informações sobre as pessoas da foto foram acrescentadas por Fábio Ottoni a partir de suas pesquisas e conhecimento pessoal da história de Caldas, sua terra natal. Foram grafadas em itálico pelo próprio Fábio no sentido de distinguir as duas fontes das informações (no caso, as que foram dadas por Paulo Guimarães e as que foram acrescidas por ele em itálico).
} 
A imagem da fotografia 3 contém no verso uma dedicatória com os dizeres seguintes: “A Tia Esperança e Tio Faustino uma lembrança das amiguinhas de Pocinhos do Rio Verde em abril de 1921". A pessoa que assinou esta dedicatória é de sobrenome Barroso. A caligrafia em que estes dizeres foram escritos também chama a atenção e fornece outros elementos que poderiam ser cotejados com mais informações no sentido de confirmar a data de tomada da imagem, bem como no tocante a buscar aproximações sobre a autoria da foto e da dedicatória, a qual pode ter sido feita algum tempo depois que a foto foi tirada.

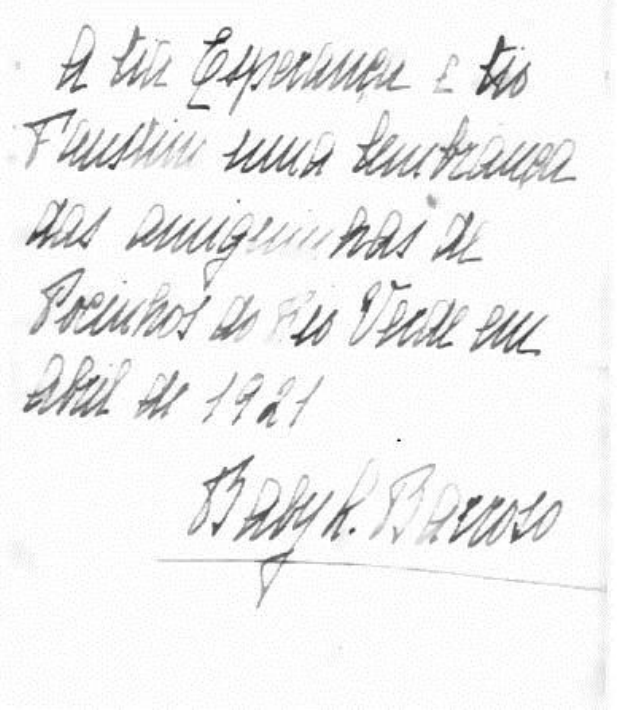

Verso da fotografia 3

No conjunto das imagens guardadas por famílias tradicionais que tomaram parte nesta pesquisa a figura de afro-descendentes é relativamente rara, o que torna esta fotografia um tanto especial. O que nos dizem o sorriso farto do casal retratado, suas posturas e gestos, suas vestimentas? O cenário de fundo pode ser identificado com facilidade, o que provavelmente não foi por acaso: uma pose junto ao Grande Hotel de Pocinhos do Rio Verde ${ }^{39}$ (estância balneária de Caldas-MG). Quem a teria tomado? Como a fotografia teria chegado aos atuais guardadores? O relato de Fábio Ottoni sobre a popularidade do casal fotografado (entre os historiadores caldenses) atribui importância e dignidade ao casal. Convida mesmo a um mergulho nos jornais antigos ${ }^{40}$ e nas histórias que poderiam também lhes ser creditadas.

\footnotetext{
${ }^{39}$ Hotel em funcionamento desde fins do século XIX.

${ }^{40}$ Fábio Ottoni reuniu e digitalizou centenas de exemplares de jornais que circularam em Caldas entre 1875 e 1965, trabalho disponibilizado às escolas do município, organizado numa caixa com 6 CDs.
} 
Por outro lado, um testemunho pessoal sobre o período da escravidão em Caldas pode ser encontrado num texto intitulado "Reminiscências", escrito em inglês por Dona Francisca Pereira de Moraes Clark (Dona Chiquita) (1868-1962) que nasceu em Caldas e lá morou até os dez anos. Dona Chiquita faleceu em Nova Jersey (EUA) e estes seus escritos foram encontrados com sua filha, Ruth Clark Spencer, quando faleceu, também nos Estados Unidos (Wooster, Ohio) em 1982. Uma neta, Annita Clark, traduziu estas "reminiscências" (escritas por Dona Chiquita entre 1930 e 1938) e fez chegar delas um exemplar aos caldenses ${ }^{41}$. Há uma seção inteira intitulada "escravos". Selecionei as passagens seguintes como expressivas da memória local do século XIX:

Tínhamos dois escravos - uma mulher e seu filho - Eva e João. Havia outro trabalho para os escravos. Quase todo mundo tinha que ter cavalos - eram os carros de hoje. Meu pai era muito orgulhoso dos seus cavalos, especialmente de Condor, que tinha a reputação de não consentir que ninguém a não ser mulher o montasse. (...) O João tomava conta dos cavalos.

Mas um dos serviços que vocês e eu pensaríamos que os escravos não gostassem de fazer era trazer a água do chafariz público, que equilibravam na cabeça dentro das latas de querosene ou em barris que vinham com vinho de Portugal. Mas eles gostavam disso. Não é surpresa, coitados, não era neste lugar que os mais velhos tinham a oportunidade de falar das dificuldades com os outros com quem se encontravam lá (...)?

Havia há muito tempo leis propostas pelos abolicionistas cuja violação fazia livres os escravos. Uma vez quando meu pai exerceu o cargo de juiz de paz, foram onze escravos que ficaram livres por causa da infração de algumas leis pelos seus patrões. Foi ele que assinou a carta de liberdade e depois da cerimônia, os presentes, os escravos e a banda da cidade acompanharam meu pai à nossa casa, onde se serviram bebidas. (...) Não entendo o que foi que fizeram aqueles escravos livres, dei toda a honra ao meu pai, e como fiquei orgulhosa! Mas, nunca pensei porque ele não libertou os seus. Um pouco depois o fez. (...). (CLARK, 1938: 18-19)

Em outra seção, Dona Chiquita fala de seus dois vizinhos suecos, André Frederick Regnell (médico que foi para Caldas em 1840 e lá faleceu em 1884) e Augusto Westin", "sobrinho do primeiro cônsul sueco mandado ao Brasil quando ficou independente de Portugal", casado com a filha de um "fazendeiro rico". A passagem seguinte fala do auxiliar de pesquisa botânica do médico André Regnell:

\footnotetext{
${ }^{41}$ Uma cópia desse trabalho datilografado me foi disponibilizada pela Sra. Olga Landi. A tradutora Annita Clark escreveu uma introdução onde cita os caldenses que lhe receberam quando visitou pessoalmente a cidade: Denise Nicoletti de Carvalho, Maria Odete de Carvalho, Tamar Dias Silvério e Sérgio Bellini (este último guarda um precioso acervo de fotografias antigas, uma das quais, mostrando a praça central em 1875, serviu de ilustração ao texto traduzido e datilografado).

$42 \mathrm{O}$ prestígio e a importância de migrantes suecos (e seus descendentes) em Caldas e em Rio Tinto parecem constituir um tema à parte para futuras problematizações.
} 
Gabriel, um escravo fiel, jovem, preto como carvão e muito inteligente o acompanhava à sua chácara com latas grandes pendentes nas costas e instrumentos para recolher flores e plantas selvagens que eram estudadas, classificadas e dissecadas em coisas especiais feitas para isso e depois mandadas para o país dele. (...) (CLARK, 1938: 20).

Em que medida, pois, as especificidades destas situações relatadas em CaldasMG teriam algo a acrescentar ao conhecimento mais geral relativo à história da escravidão, produzido principalmente a partir de cidades maiores como Salvador ou Rio de Janeiro? Como dimensionar a importância das personagens retratadas na fotografia 3 para novas pesquisas e relatos sobre o período de escravidão em Caldas? Um pequeno artigo de Miriam Moreira Leite que procura resenhar algumas obras sobre o tema nota o seguinte:

(...) O centenário da abolição da escravatura, em 1988, teve o mérito de estimular o resgate e a organização de fontes primárias e secundárias sobre a população negra, sobre a escravidão e sobre a abolição além da publicação de obras de rediscussão desses problemas. A invisibilidade do negro e do índio já tem sido tratada de diversas formas, na literatura e nas ciências sociais. No caso da fotografia, a raridade ou ausência de registros acabavam fazendo com que as existentes ganhassem foros de realidades únicas. (LEITE, 1996: 146)

Embora o período da fotografia 3 já seja posterior ao século XIX, não é novidade que o problema da invisibilidade do afro-descendente permaneceu durante $\mathrm{o}$ desenvolvimento das sociedades republicanas no Brasil. Veja-se, passados mais de cem anos da abolição, a difícil busca por reconhecimento das comunidades Quilombolas nos dias atuais ${ }^{43}$. Contudo, por mais que estas reminiscências e questões possam ser levantadas a partir da fotografia 3, somente estudos mais detidos da mesma, com devidas contextualizações de várias ordens e contribuições de vários testemunhos (inclusive dos possíveis descendentes destes que foram escravizados no passado ${ }^{44}$ ) poderiam nos dar uma dimensão mais próxima e adequada da trajetória e do sentido desta fotografia.

\footnotetext{
${ }^{43} \mathrm{O}$ direito legítimo às terras que ocupam só foi reconhecido na constituição de 1988 (ADCT, art. 68).

${ }^{44}$ Uma pesquisa dessa ordem encontraria talvez muitas dificuldades, mas poderia ser realizada (por alguém já familiarizado com os possíveis informantes) inicialmente com a população idosa do bairro da Santa Cruz; neste sentido o lugar histórico e cultural dos "negros" certamente merece estudos e esclarecimentos que permitam dar visibilidade e ampliar a compreensão das suas condições de vida no passado e no presente.
} 


\section{Fotografia 4: do carro de bois à "poeira"}

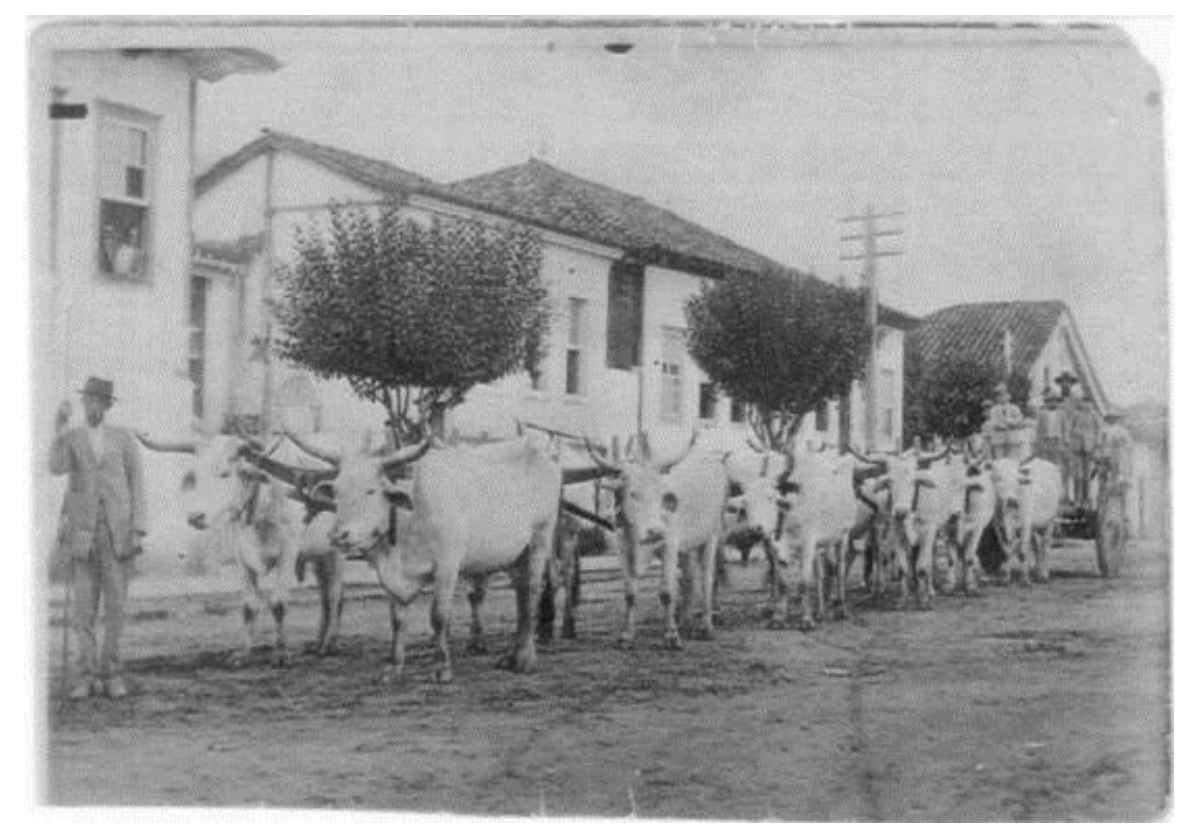

Fotografia 4: autor não identificado/ Acervo de Paulo Guimarães - década de 30[?]

\section{Foto: "Carro de Bois"}

Data: Possivelmente década de 30, talvez meados da década.

Local: A foto foi feita na praça central de Caldas, atualmente Praça Paiva Oliveira.

Pessoas: Em primeiro plano o proprietário do carro de bois, Sr. Manoel Dias de Carvalho (bisavô do Piu). Este senhor gostava muito de carros de bois. Neste caso chama à atenção a quantidade de bois atrelados ao carro: 12 bois. Ao fundo, ou seja, sobre o carro de bois, entre as cinco crianças o Sr. Joaquim Carro, aquele que conduzia o carro de bois, ou seja, tocava os animais. ${ }^{45}$

Cenário: Ao fundo, perfilados, alguns dos antigos casarões que ladeavam a praça central nesta época. A primeira casa, à esquerda, ou na parte dela que aparece na foto observa-se na janela os proprietários da mesma: Afonso D'Ambrosio e sua esposa Clarisse. Entre esta primeira casa e a segunda há um espaço onde havia uma escadaria que dava acesso a entrada para a primeira casa (um hotel e também residência). Era também através desta entrada que se chegava a um cinema e salão de danças nos fundos desta primeira casa. Este cinema que também servia como salão de bailes era conhecido como "Poeira". Nome este devido ao fato do recinto ter o chão de terra batida o que obviamente causava muita poeira, principalmente durante os bailes. A segunda e a terceira casa ainda existem, embora irreconhecíveis, ambas com as fachadas muito alteradas. A terceira inclusive, com toda a frente, subdividida em três recintos comerciais, uma pequena loja, um bar, e uma casa lotérica. Entre a terceira e as duas últimas casas que aparecem na foto há uma rua ou um beco. As últimas duas casas já não existem mais, foram demolidas há muitos anos. As três árvores que

\footnotetext{
${ }^{45}$ Informações da data, local e pessoas foram obtidas por Fábio Ottoni junto ao Paulo Guimarães (de cuja família provém estas fotografias).
} 
aparecem na foto fazem parte de um conjunto de arvoredos que se perfilavam no largo entre a Igreja Matriz e a Igreja do Rosário, ou seja, de um lado ao outro extremo da praça. $^{46}$

A fotografia do carro de bois e as informações a ela agregadas chamam a atenção pela quantidade de detalhes observáveis ${ }^{47}$ e identificados com precisão (personagens, animais, crianças, árvores, casas, pessoas na janela, etc.) pelo texto. A organização das informações pode ser dividida em dois planos: o primeiro, referente ao próprio carro de bois e, o segundo, sobre os antigos casarões que aparecem logo atrás. A fotografia, posada, foi possivelmente destinada a mostrar o lado austero e próspero deste proprietário e de sua família. Essa leitura, talvez até muito óbvia, não esgota, contudo, outros sentidos trazidos por esta imagem no conjunto da pesquisa. $\mathrm{O}$ cenário de fundo, com o casario antigo, já constitui um assunto a mais, como bem indicam os comentários de Fábio Ottoni. Vejamos onde mais este carro de bois pode levar.

Primeiramente, se tomo o conjunto das imagens apresentadas na exposição comemorativa de aniversário da cidade pode-se constatar que não há ali fotografias de carros de bois. Como esclarecer e dimensionar a importância desse meio de tração animal naquela época ou mesmo antes? Seria comum trazer carros de bois à praça, seria parte de um percurso habitual? Existem outras fotografias de carros de bois (desta ou de outras famílias) que pudessem alargar a compreensão desta cena passada? Os depoimentos possíveis de serem obtidos com diversos membros da família certamente trariam mais informações sobre este carro de bois, talvez possam revelar que a motivação para a foto (sentido implícito no fato de que ele "gostava muito") vai um pouco além do registro habitual de posses e bens.

Outro sentido surge quando associo esta imagem com a fotografia anterior, pelo fato de ambas pertencerem ao acervo de uma mesma família. A trajetória da fotografia anterior (fotografia 3) atrelada, desta vez, às fotografias da família de Paulo Guimarães, permite levantar as seguintes questões: o fato de que as imagens de Tia Esperança e Tio Faustino estejam entre as fotografias de uma família cujos ascendentes foram proprietários e fazendeiros (retratados entre os anos trinta e quarenta) pode lançar luz na

\footnotetext{
${ }^{46}$ Estas informações sobre o cenário da foto foram acrescentadas por Fábio Ottoni a partir de suas pesquisas e conhecimento pessoal da história de Caldas. Foram grafadas em itálico pelo próprio Fábio no sentido de distinguir as duas fontes das informações (no caso, as que foram dadas por Paulo Guimarães e as que foram acrescidas por ele, em itálico).

${ }^{47}$ Muito embora a reprodução digital apresentada aqui tenha perdido parte da nitidez do artefato original, deve-se notar que as informações levantadas provêm de situações onde o original pôde ser consultado diretamente.
} 
questão de saber um pouco mais sobre a trajetória mais longínqua daquelas personagens? Que tipo de ligação haveria entre a trajetória dos ex-escravos e as trajetórias dos familiares de Paulo Guimarães (que em algum ponto de uma rede social, num dado momento, se encontraram, quando o artefato fotográfico achou seu atual lugar)? Saber por quem a fotografia 3 veio a tomar parte no acervo da família seria o primeiro passo de uma busca que não necessariamente produziria resultados significativos.

De volta ao tema do carro de bois, quero apontar para o relato de Dona Chiquita (referida há pouco), acerca de experiências vividas na mesma praça várias décadas antes. Ela fala da circulação de animais, entre outros aspectos da pequena "vila" e do "largo" (hoje praça Paiva Oliveira) em fins do século XIX:

(...) naquele tempo nenhuma cidadezinha teve outra luz do que a fornecida pela velha e bondosa lua. Era um pouco perigoso atravessar o grande largo nas noites escuras, porque a gente poderia tropeçar em alguma coisa e no instante seguinte descobrir que era uma vaca! (...) (CLARK, 1938: 5-6)

Na mesma época o uso dos carros de bois como meio de viajar (e não apenas de transportar carga) era uma possibilidade, como relatou Dona Chiquita ao falar das viagens planejadas com um de seus primos:

(...) Só uma vez desde que fiz cinco anos tinha atravessado os limites da cidade quando a família inteira foi numa carroça, sem molas, coberta com couro, com rodas grandes e sólidas, puxada por oito ou dez bois, para visitar amigos na sua fazenda. Ficamos lá alguns dias. Nunca pude esquecer aquela viagem com os solavancos - deixou uma impressão grande no meu corpo inteiro. (CLARK, 1938: 24)

Ver-se-á, na seção seguinte, que atualmente as crianças em Caldas ainda podem experimentar a sensação de serem levadas em carros de bois.

\section{Fotografias 5 a 8: atualidade dos carros de bois na praça central}

Muitas vezes o assunto abordado pela fotografia antiga encontra-se hoje, em alguma medida, retomado continuamente por outros fotógrafos. Imagens mais atuais, de um salto, permitem refletir sobre como o uso de carros de bois em Caldas chegou até o século XXI. O som emitido pelas rodas dos carros de bois, por dezenas de carros de bois circulando na praça (antigo "largo"), ouvido mais de cem anos depois, foi motivação principal das fotografias seguintes, tomadas por mim em 31 de julho de 2004. Improviso os comentários que acompanham as imagens, mas evidentemente que 
os comentários dos próprios sujeitos (moradores e mesmo os que aparecem retratados) alargariam em muito a compreensão destas cenas ${ }^{48}$.

A seqüência das três fotografias seguintes ${ }^{49}$ mostra dois pontos do trajeto seguido durante o desfile de carros de bois: o centro da praça, totalmente plana com árvore e casarões ao fundo, e a rua por onde os carros deixam a praça, numa descida acentuada. A quarta fotografia fornece uma visão mais próxima de um dos carros e do jovem que o acompanha.

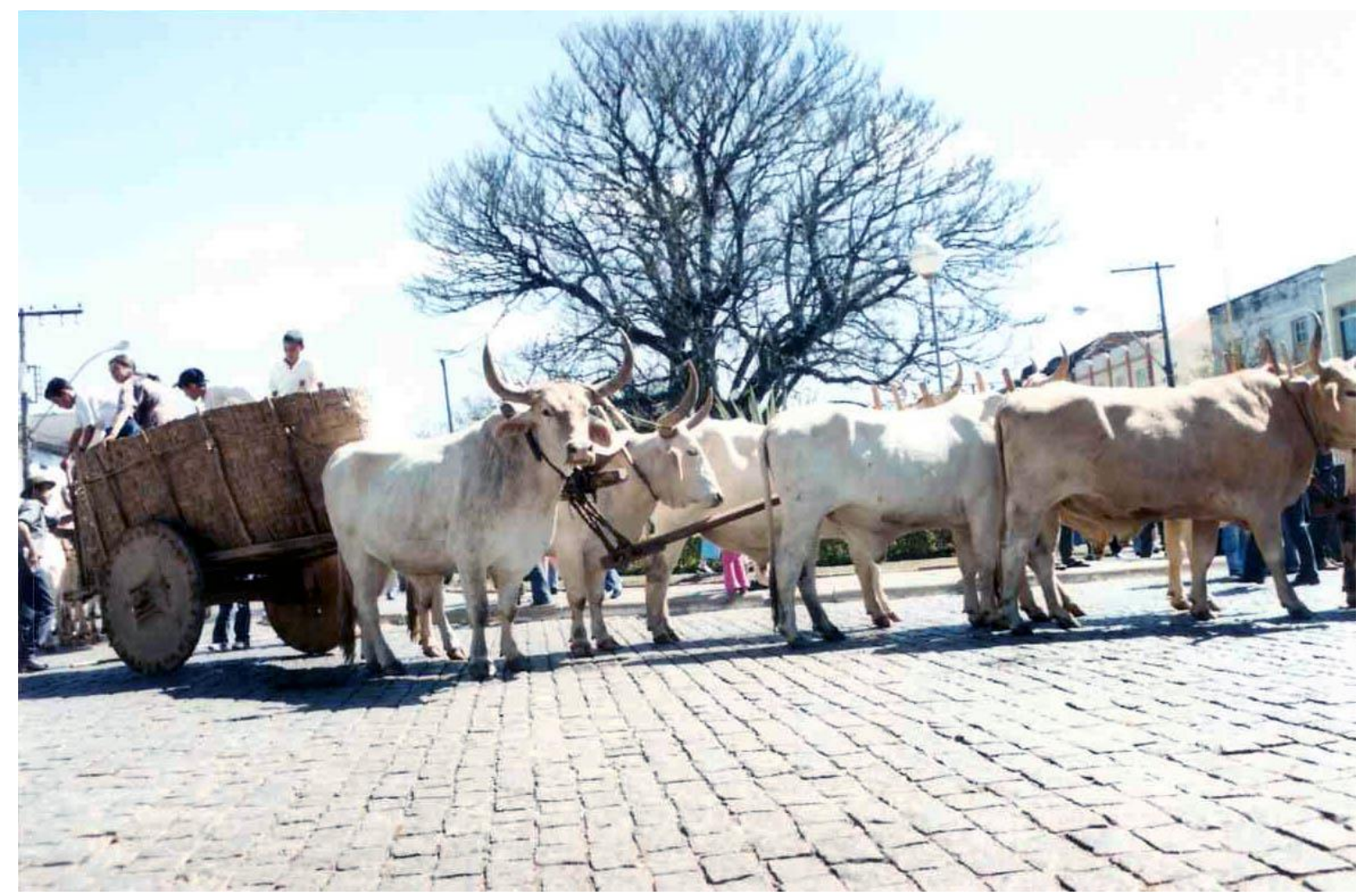

Fotografia 5: Acervo do autor - manhã 31 de julho de 2004.

\footnotetext{
${ }^{48}$ Hoje o desfile anual dos carros de bois em Caldas é fotografado e veiculado na internet e na imprensa local (o que não quer dizer que as imagens sejam suficientemente analisadas e compreendidas no sentido etnográfico e colaborativo aqui esboçado a partir de fotografias já existentes). Ver, por exemplo: <http://www.hotelrioverde.com.br/textos/galeria/2009_09_carrosdeboi.html>. Acesso em 10nov2011.

49 As imagens seguintes fazem parte do acervo do autor, mas não foram originalmente concebidas para nenhum projeto específico, que não o exercício fotográfico numa situação digna de interesse especial (Câmera Pentax K-1000, lente 35-80 mm, filme Kodak Gold - ASA 100).
} 


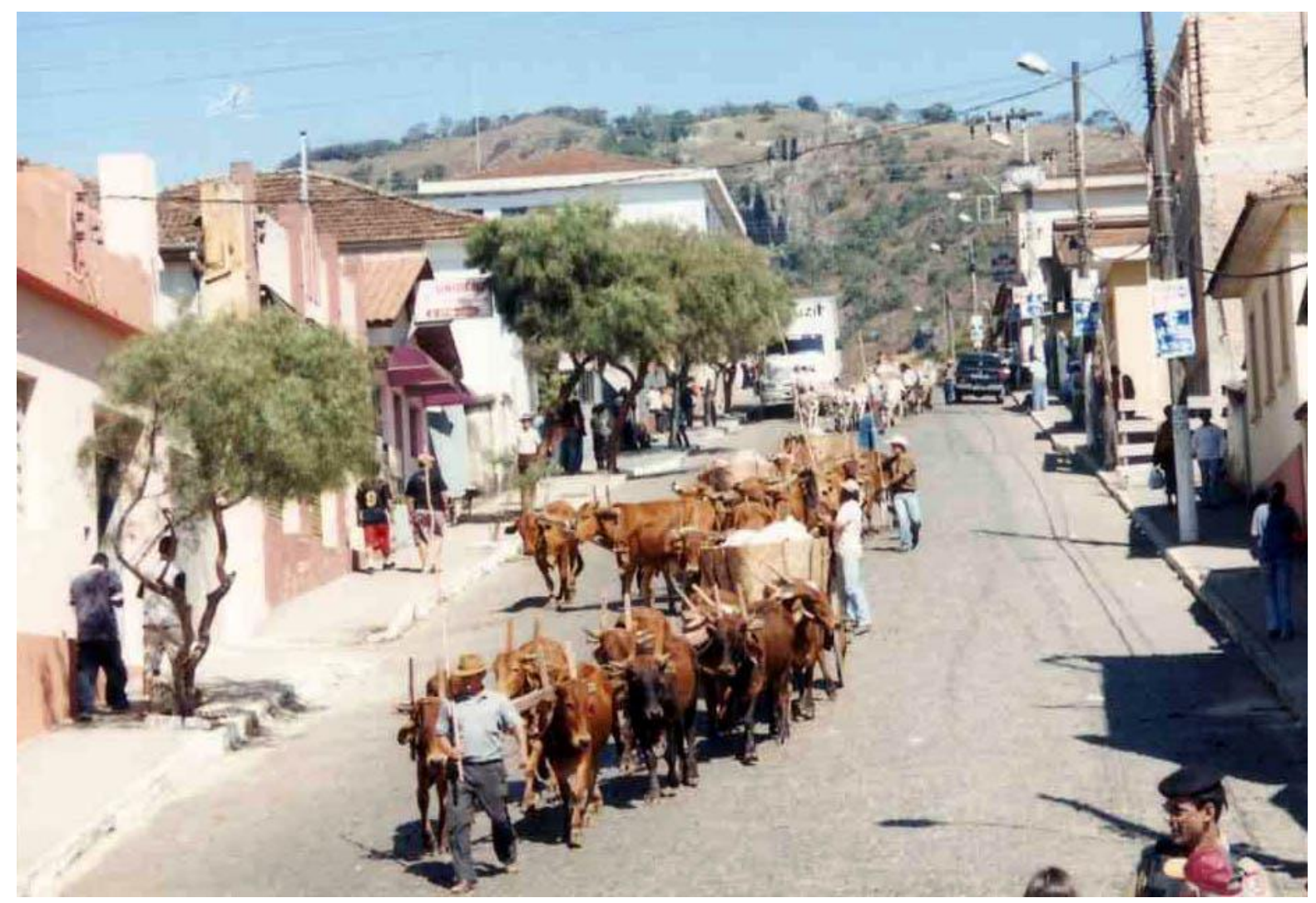

Fotografia 6: Acervo do autor - manhã 31 de julho de 2004.

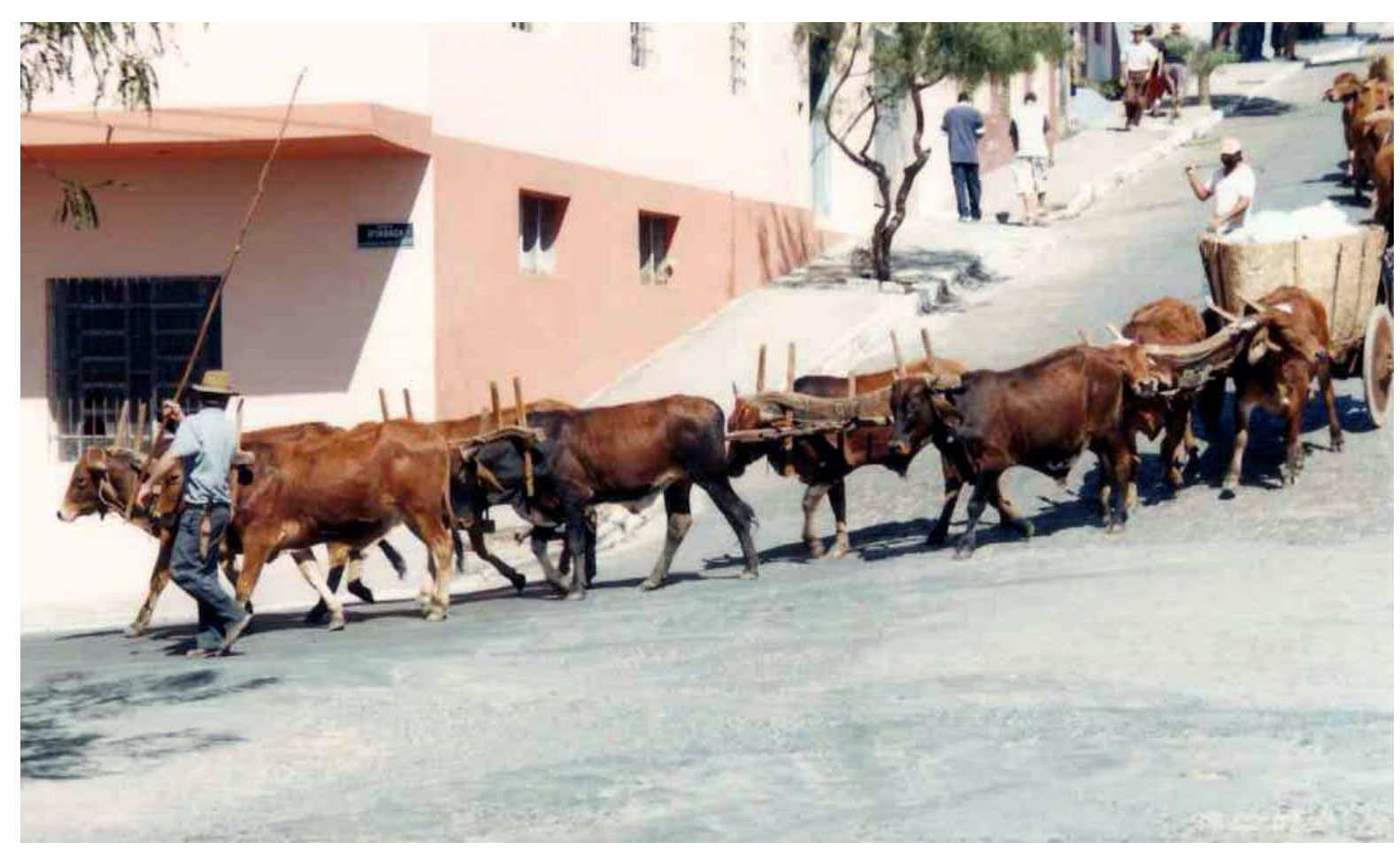

Fotografia 7: Acervo do autor - manhã 31 de julho de 2004. 


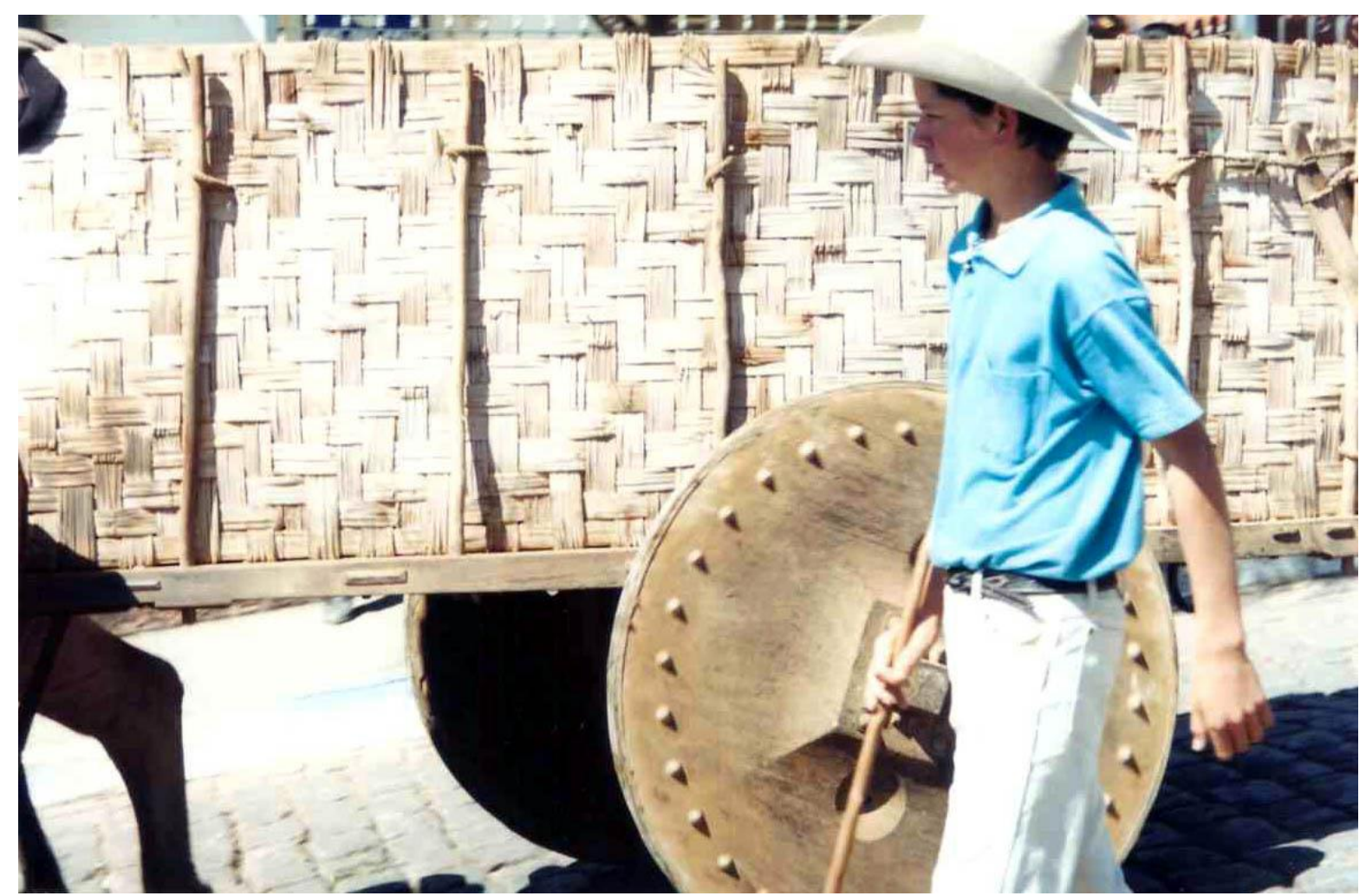

Fotografia 8: Acervo do autor - manhã 31 de julho de 2004.

Cada fotografia mereceria aqui um comentário mais detalhado e elaborado ${ }^{50}$ juntamente com os participantes deste desfile, para quem a antiga fotografia do carro de bois poderia também provocar reflexões. Noto apenas o hábito de levar crianças em cima (apenas enquanto o carro passa pela praça, ver fotografia 5), junto aos mantimentos (milho, feijão, etc.) que são carregados nos carros para serem oferecidos em caráter beneficente: esse o objetivo final do trajeto (após a descida da praça, ver fotografias 6 e 7). O "carro" propriamente dito e suas rodas, "grandes e sólidas" (ver fotografia 8), junto ao jovem vestido à caráter indicam continuidade do aprendizado de todo um conjunto de técnicas necessárias ao uso dos carros de bois. Note-se, por exemplo, a gestualidade do condutor que está à frente durante a descida (ver fotografia 6, o declive e as pedras de paralelepípedo constituem dificuldades) e na curva ao final da mesma (ver fotografia 7).

Por outro lado um assunto secundário pode ser percebido no conjunto das fotografias 5, 6 e 7: a localização da praça em relação ao relevo montanhoso da

\footnotetext{
${ }^{50}$ Deixarei para outra ocasião uma abordagem mais detida (e informada etnograficamente) das imagens (antigas e atuais) dos carros de bois.
} 
cidade $^{51}$. A maior parte dos moradores "sobe" até a praça e depois "desce",52, seja para ir à missa, ao banco, ao bar, etc. Os becos e fundos comentados por Fábio Ottoni em relação à fotografia 4 são provavelmente constituídos nesse mesmo sentido descendente. Os usos e os significados do espaço podem, então, vir à tona numa pesquisa fotográfica que não se restrinja aos assuntos principais, o que amplia o leque da investigação em muitos casos, sobretudo quando aspectos dos espaços públicos aparecem.

Ao fim deste percurso com as imagens dos carros de bois, entrevemos cenas e experiências do passado mais distante (séc. XIX) e bem mais recente (2004), além de percebermos um pouco do espaço da praça central, de seus casarões, becos, cinemas, bailes e personagens. Espero assim ter apontado para alguns elementos de pesquisa fotográfica e para as várias possibilidades de seu tratamento. Cabem aqui também as considerações apresentadas sobre as imagens abordadas mais atrás (fotografias 1, 2 e 3).

Buscou-se exercitar minimamente a constituição de um conhecimento fotográfico que tem na imagem o lugar central ${ }^{53}$. É a partir de onde outras imagens e informações verbais são levantadas, não muito além do limite dado pelo que pode ser visualizado, total ou parcialmente, nas próprias fotografias. Contudo, esse um pouco além (do que pode ser visualizado) que a informação verbal pode trazer não deixa de ter muita importância na medida em que vai às vezes ilustrar a imagem (e não o contrário) e/ou mesmo revelar algo fundamental para além dela (até mesmo para além do visível).

Encerro aqui os apontamentos sobre as fotografias de Caldas e passo a considerar brevemente a pesquisa fotográfica que iniciei em Rio Tinto-PB.

\section{Pesquisa fotográfica em Rio Tinto}

Rio Tinto fica no litoral norte do estado da Paraíba ${ }^{54}$ (pertence hoje à grande região metropolitana de João Pessoa) e abriga um novo Campus da UFPB, instalado a partir de 2006. O projeto de pesquisa relativo ao município foi apresentado, já em fins de 2008, como pré-requisito à inscrição para o concurso de provas e títulos para o cargo

\footnotetext{
${ }^{51} \mathrm{Na}$ fotografia 6 pode-se ver, ao fundo, a montanha onde fica a "Pedra do coração", um dos destinos turísticos de Caldas (já referido) de onde pode-se avistar toda a cidade.

${ }^{52}$ Referência às expressões locais, como quando se diz "ele já subiu”, significa que ele está na praça.

${ }^{53}$ Como fio condutor ou referência de base para onde se retornará constantemente e por onde se tentará buscar o exercício de uma linguagem analítica, a um só tempo, visual e verbal.

${ }^{54} \mathrm{O}$ município de Rio Tinto foi emancipado e desmembrado da atual cidade vizinha de Mamanguape em 1956, quase quarenta anos depois de surgir como vila operária em função da instalação de uma fábrica de tecidos em terras de engenho de cana, ladeadas por áreas de ocupação indígena (Potiguara).
} 
de professor na área de antropologia visual. Depois foi reformulado e submetido em 2009 para obtenção de apoio junto ao CNPQ através de um edital específico para novos campi universitários $^{55}$. Propõe uma pesquisa exploratória em Antropologia Visual, a qual parte do levantamento de fotografias antigas e de hábitos visuais, com vistas à produção de conhecimentos que se utilizem da imagem e do som em sentido parcialmente semelhante ao que se buscou realizar em Caldas-MG.

Vale notar como as situações de pesquisa foram bastante diversas nos dois casos. Desta vez, ao contrário do que havia ocorrido em Caldas, não foi como morador que concebi o projeto, mas como docente-pesquisador do novo Campus recém-instalado em Rio Tinto (a $50 \mathrm{~km}$ de João Pessoa, onde moro). No primeiro caso, então, a pesquisa surgiu após mais de um ano de interações locais como efetivo habitante da cidade. No outro, ela foi condição prévia do meu trabalho como professor universitário e decorreu de interações locais estabelecidas a partir do trabalho universitário e do projeto proposto $^{56}$.

O fato do município de Rio Tinto possuir áreas indígenas Potiguara em seu território, por exemplo, levou-me a incluir perspectivas de abordagem das imagens a partir destes moradores em especial, o que inclui a busca de fotografias e hábitos visuais junto deles próprios, particularmente na aldeia Monte-Mor, situada em área urbana. Fotografias e imagens históricas dos Potiguara também são levantadas. Em Caldas, que também possui uma área indígena na sua zona rural desde 2002 (Xucuru-Kariri), essa perspectiva não chegou a ser explorada.

Os primeiros contatos pessoais significativos estabelecidos para a pesquisa foram feitos, portanto, durante o "Seminário Memória e Imagem no Vale do Mamanguape" 57 (entre 6 e 9 de outubro de 2009), quando tivemos convidados locais (inclusive fotógrafos), líderes indígenas e um convidado vindo do Museu Nacional, Prof. José Sérgio Leite Lopes, o qual apresentou e discutiu seu filme, feito com

\footnotetext{
${ }^{55}$ Diversos estudantes têm trabalhado neste projeto, como parte de sua iniciação científica (Antonio Pedro Soares, Danilo Alex Marques de Farias, Ana Amélia de Araújo Lima, Luana Maia Pinto e Marianna de Queiroz Araujo). O tempo dedicado à pesquisa, em Rio Tinto, é dividido com o tempo dedicado à docência e às outras tarefas acadêmicas.

${ }^{56}$ Espero refletir melhor, no futuro, sobre as implicações destas diferenças em termos dos tipos de inserção do pesquisador nos locais estudados.

${ }^{57}$ Iniciativa do curso de graduação em antropologia da UFPB/Rio Tinto. Hoje funciona em Rio Tinto e João Pessoa um curso de mestrado em antropologia <www.cchla.ufpb.br/ppga> .
} 
Rosilene Alvim e Celso Brandão, intitulado Tecido Memória ${ }^{58}$ (sobre trabalhadores das Fábricas de Tecido do município de Paulista-PE) ${ }^{59}$.

Através deste primeiro contato com fotógrafos locais e com ex-trabalhadores da fábrica de $\operatorname{tecidos}^{60}$ procurei levantar informações sobre pessoas que guardassem fotografias ou mesmo memórias das épocas passadas. Logo fui conduzido à Fundação Cultural da cidade onde ficam abrigados os cinco painéis com cento e cinqüenta e três fotografias que foram exibidas na praça por ocasião do aniversário da cidade em 2006. Foi possível encontrar estas mesmas imagens também disponíveis na internet ${ }^{61}$.

Esse material imagético constitui outro assunto a ser tratado numa possível comparação entre os dados da pesquisa fotográfica em Caldas-MG e Rio Tinto-PB, municípios com populações numericamente aproximadas. Uma das primeiras diferenças a ser notada é o fato de que em Caldas fotografias emprestadas de várias famílias foram reproduzidas e exibidas, numa espécie de exposição coletiva, ao passo que em Rio Tinto um único colecionador (que guarda e também coleta fotografias com outros moradores) foi o principal responsável pela exposição.

Outra diferença a ser notada é que em Caldas a pesquisa chegou a levantar nomes de fotógrafos mais antigos ${ }^{62}$ a partir do contato com membros das famílias locais (com quem a pesquisa teve início). Já em Rio Tinto foi primeiro através do contato com fotógrafos mais antigos na cidade que foi possível chegar a conhecer outras famílias locais que mantinham fotografias antigas guardadas. Isso implicou em levantamento de histórias de vida dos fotógrafos (junto deles ou de seus descendentes) como forma de esclarecer a permanência e a importância das imagens fotográficas.

\footnotetext{
58 Filme documentário premiado em 2010 pela Associação Brasileira de Antropologia <www.abant.org.br>.

${ }^{59}$ Realizamos também visitas de pesquisa na casa de ex-trabalhadores da fábrica de tecidos de Rio Tinto (a qual pertenceu aos mesmos donos da fábrica de Paulista-PE) bem como no casarão construído pelos donos da fábrica, na época em processo de desapropriação pelo governo federal em virtude de estar localizado em atual área indígena.

${ }^{60}$ A fábrica de tecidos foi inaugurada em 1924, posteriormente tornou-se a "Companhia de Tecidos Rio Tinto", fornecedora das conhecidas "Lojas Pernambucanas" espalhadas em várias cidades brasileiras.

${ }^{61}$ Imagens da festa onde foram exibidas originalmente as fotografias antigas dispostas em painéis de madeira. Disponível em: 〈http://www.riotintopb.com.br/f5read/galeria/galeria.php?varimg=143>. Acesso em 19nov2010. Como também a maior parte das imagens exibidas nos painéis, acompanhadas, desta vez, de mais legendas e detalhes. Disponível em: <http://www.riotintopb.com.br/f5read/galeria/galeria.php?varimg=151>. Acesso em 19nov2010. Esta exposição foi produzida pelo Dr. Antonio Luiz (colecionador local) e pelo fotógrafo Hildebrando Domingos. A este último agradeço o apoio e as informações prestadas à pesquisa, como também aos fotógrafos Antonio Fernandes (Toinho) e Ednaldo Félix.

${ }^{62}$ Como Hélio Ramos, Jurandir Castilho e J. Pereira. Não cheguei a ter tempo para fazer contato com nenhum deles, nem com seus descendentes, embora houvessem indicações suficientes para que fossem encontrados.
} 
Posteriormente, ao notar moradores que colecionam ou colecionaram fotografias (para além da esfera dos contatos e interesses familiares), procurei atentar um pouco mais para o sentido das "práticas culturais" de colecionamento (Gonçalves, 1999: 25). Resta, no entanto, muito ainda a ser feito nas várias frentes de trabalho que se abriram desde então.

O acervo reunido para pesquisa já conta com centenas de imagens em preto e branco, as quais são digitalizadas em pequenos lotes e imediatamente devolvidas aos seus guardadores, com algumas orientações básicas para sua conservação. A prática de "foto-elicitação" (Banks, 2009: 82) (Collier Jr., 1973: 67-98) também tem sido experimentada como forma de obtenção de informações sobre as imagens reunidas. É dada especial atenção à relação entre as imagens e aqueles que as mantiveram guardadas de maneira a que as especificidades de cada acervo familiar ou coleção particular possam ser esclarecidas.

Uma série de questões tem sido levantada neste outro contexto de pesquisa e freqüentemente situações vivenciadas na pesquisa fotográfica em Caldas ajudam a refletir para além do contexto local de Rio Tinto. Qual o lugar das imagens fotográficas mais antigas nas instituições locais (prefeituras, escolas, bibliotecas, etc.)? Que relações de poder são expressas pela prática do colecionamento e da exibição de fotografias antigas, bem como pela própria participação numa pesquisa fotográfica universitária? Como esclarecer a dimensão afetiva presente na manutenção de acervos fotográficos familiares ou mesmo em coleções particulares? Qual o lugar dos fotógrafos e o sentido de suas práticas junto às instituições e clientes particulares? Que relações podem ser estabelecidas entre as práticas fotográficas mais antigas e as atuais, pelas quais imagens digitais são produzidas e circulam em ambientes virtuais? De que maneira a visualidade (das imagens técnicas) se constituiu, a partir da fotografia (e depois: cinema, televisão e atuais computadores) como um elemento cada vez mais presente na sociedade e na cultura? Que importância têm as imagens nas práticas de sociabilidade?

Enfim, outras tantas questões poderiam ser elencadas e sua discussão ficará reservada para outro momento, quando espero sistematizar melhor e apresentar mais detidamente os resultados da pesquisa fotográfica em Rio Tinto. Bastará aqui retomar o conjunto dos apontamentos dados para propor as seguintes considerações finais. 


\section{Entre Caldas e Rio Tinto: em busca do conhecimento fotográfico}

Nas duas cidades pequenas consideradas as fotografias antigas estão na casa de famílias, em geral um dos familiares se interessa mais pela guarda das mesmas que pode ser feita de modo mais ou menos organizado, sejam fotografias avulsas ou acondicionadas em álbuns. Mesmo que sejam poucas fotografias guardadas, elas estão muitas vezes plenas de significados afetivos (entre outros) e por esta mesma razão são às vezes cedidas para outros familiares e/ou amigos, prática que se insere numa rede de relações de trocas mais ampla. Fotografias antigas podem circular das famílias para as mãos de colecionadores locais cujas intenções podem ser de várias ordens. Enquanto as fotografias estão reunidas em acervos familiares, maiores são as chances de identificação dos assuntos e mesmo das tecnologias e fotógrafos envolvidos na produção das imagens.

Além de terem se constituído a partir de diferentes acontecimentos e relações sociais situados no passado (remontam, no máximo, aos anos vinte) ${ }^{63}$, as fotografias reunidas e conservadas em famílias são resultado de processo de seleção (quando diversas outras fotografias podem ter sido descartadas pelos mais variados motivos). $\mathrm{O}$ conhecimento e as lembranças pessoais acerca de sujeitos ou situações que aparecem fotografados estão entre os principais motivos para a permanência de fotografias guardadas. Quando se observa a prática do colecionamento por sujeitos particulares (quando fotografias diversas são reunidas e mantidas por uma pessoa), diferentes motivações podem estar presentes, sejam de natureza histórica, política, estética ou outras. Nestes casos o contato com o próprio colecionador, quando isso é possível, contribui ao esclarecimento dos assuntos e das origens de sua coleta. Tanto num caso como em outro é possível contar ainda com esclarecimentos obtidos a partir de terceiros ou de fontes escritas correlacionadas.

Os conhecimentos paralelos possíveis de serem descobertos em fotografias (aqueles que aparecem na foto além do assunto principal, sejam no fundo ou em outros planos, mesmo quando desfocados) constituem elementos importantes da pesquisa fotográfica, às vezes estão ali por acaso ou por sua presença ter sido inevitável, embora nem sempre desejável. Nestes casos a consideração da fotografia vai além das intenções ou expectativas de quem as fez produzir ou guardar e permite incluir na análise

\footnotetext{
${ }^{63}$ Embora em Caldas existam algumas fotografias anteriores à década de 20. Em Rio Tinto, na medida em que a cidade se origina de uma vila operária edificada a partir de 1917, torna-se possível perceber todo o período de desenvolvimento da prática fotográfica ao longo do século $\mathrm{XX}$, em que pese a perda de inúmeros documentos escritos e fotográficos (por destruição intencional ou deterioração).
} 
elementos que não são da mesma ordem de preocupações que motivou a produção da imagem, muitas vezes ligada à vontade de uma família (ou outra instituição) se fazer representar por meio de imagens que lhes registrem os feitos e a posição social (expressões de uma elite local ${ }^{64}$. Em sentido semelhante, pessoas de outras posições sociais podem contribuir (nas práticas de foto-elicitação) ao conhecimento fotográfico, com visões (e projeções) alternativas sobre as mesmas imagens.

Os detalhes do trabalho fotográfico e a história de vida dos fotógrafos locais constituem elementos indispensáveis à pesquisa. Por esta via descobrem-se técnicas, processos, câmeras, formas de cooperação familiar na revelação e ampliação de fotografias, estratégias de competição comercial bem como modos de transmissão do ofício às novas gerações. Além disso, são fontes privilegiadas para o conhecimento dos eventos e das famílias locais.

No Brasil o Dicionário Histórico-Fotográfico de Boris Kossoy (Kossoy, 2002) tornou-se a principal referência para o estudo da prática fotográfica desde o século XIX, ele inclui referências aos fotógrafos que se estabeleceram ou que anunciaram seus serviços nas principais cidades brasileiras entre 1833 e 1910. A multiplicação de fotografias e fotógrafos e suas transformações ao longo do século XX está a requerer mais pesquisas, campo que se estende para muitas outras cidades de menor porte.

Na Paraíba, pelo menos dois trabalhos podem ser encontrados sobre a fotografia praticada no século XIX e na primeira metade do século XX: são os livros de Bertrand Lira sobre a fotografia a partir de João Pessoa (Lira, 1997) e de Paulo Matias Figueiredo Júnior sobre fotógrafos que atuaram em Campina Grande (Figueiredo Jr., 2005). A conhecida itinerância dos fotógrafos pelo interior em busca de clientes, bem como as viagens realizadas por moradores do interior às grandes cidades constituíram momentos em que fotografias foram produzidas, ofertadas e guardadas (Lira, 1997: 38-41).

O desenvolvimento da fotografia em Rio Tinto, assim, está inevitavelmente ligado aos processos de itinerância dos fotógrafos entre cidades próximas, principalmente Mamanguape ${ }^{65}$, que já tinha pelo menos um estúdio fotográfico fixo em 1910 (Lira, 1997: 209-210). Por outro lado, a prática da fotografia desde os fins do século XIX não se dissocia dos processos de urbanização instaurados a partir da primeira república (luz elétrica, bondes, edificações, etc.). A pesquisa em pequenas

\footnotetext{
${ }^{64}$ Houve provavelmente, no entanto, muitos outros tipos de motivações possíveis para a realização de fotografias ao longo deste século XX.

${ }^{65}$ Que fica a menos de $10 \mathrm{~km}$. Foi de onde Rio Tinto se desmembrou em 1956.
} 
cidades como Rio Tinto e Caldas, portanto, contribui para a compreensão da prática fotográfica que se estendeu para além das capitais e grandes cidades ${ }^{66}$, nos períodos republicanos posteriores ao século XIX.

O sentido histórico das imagens foi privilegiado quando se tratou de reunir diversas fotografias antigas numa exposição, como parte de comemorações cívicas ligadas aos dois municípios abordados. A possibilidade de digitalização das imagens somou-se ao caráter festivo e permitiu a ampliação da exposição para a dimensão virtual bem como para outros propósitos relativos à pesquisa histórica e fotográfica. A disponibilização de fotografias antigas em sites, a exemplo do que ocorreu em IpuiúnaMG e Rio Tinto-PB, levanta a questão da permanência destas imagens através de novas tecnologias, as quais também podem ser usadas como ferramentas de pesquisa.

A dimensão colaborativa da pesquisa fotográfica foi realizada, em Caldas, na medida em que a relação estabelecida com um morador, pesquisador local, permitiu colocar em prática alguns aspectos das estratégias de pesquisa previstas no trabalho de Bóris Kossoy (Kossoy, 2001: 89-95), sobretudo no que diz respeito às "informações referentes ao assunto (tema representado na imagem fotográfica)" e sua indexação a diferentes informantes. Em Rio Tinto outras formas de trabalho colaborativo são possíveis, por exemplo, na medida em que estudantes de famílias locais ingressaram no curso de antropologia e passaram a participar do projeto.

No trabalho com moradores idosos foi notado, durante práticas de fotoelicitação, que a identificação de personagens ou assuntos efetivamente pode variar em muito de acordo com as memórias de quem fala (e projeta suas experiências passadas) sobre a imagem. Por exemplo, um personagem identificado numa fotografia, cuja história de vida (e de morte) foi longamente recuperada, não foi identificado como o mesmo na medida em que a mesma imagem foi mostrada para outra família. Esta personagem foi reconhecida seguramente como sendo outra pessoa, notaram inclusive (quando mencionei a possibilidade de que se tratasse de Antonio ${ }^{67}$ ) que conheciam esse Antonio, mas que certamente ele não era o sujeito que aparecia naquela foto. A dimensão colaborativa do trabalho de pesquisa fotográfica e as formas que pode assumir dependem, em todo caso, do equacionamento das motivações e expectativas dos moradores locais.

\footnotetext{
${ }^{66}$ Onde pesquisas fotográficas encontram-se em estágios mais avançados, às vezes com instituições encarregadas da conservação de coleções e acervos de imagens.

${ }^{67}$ Nome fictício.
} 
O sentido etnográfico e antropológico das imagens fotográficas (inclui-se aqui a dimensão colaborativa como forma de restituição aos sujeitos pesquisados) foi condicionado ainda ao desenvolvimento de um método analítico que propicia o exercício de uma linguagem a um só tempo visual e verbal (com base na conjugação de técnicas e métodos de antropologia visual e história oral). Neste caso, as motivações e expectativas da análise vão mais além do interesse pela história local e se abrem para novos questionamentos, generalizações e comparações a partir das quais são elaborados conhecimentos que possam contribuir às reflexões $\mathrm{e}$ decisões atuais (e ao desenvolvimento de outras pesquisas). Este sentido pode ser aproximado àquilo que propõe Scherer:

\footnotetext{
“(...) nem a fotografia como artefato, nem a interpretação de seu objeto pelo espectador, nem a compreensão da intenção do fotógrafo podem fornecer isoladamente um significado holístico às imagens. É apenas olhando para os três como partes de um processo, de preferência em referência a grupos de imagens relacionadas, que se pode extrair das fotografias um significado sociocultural relevante. (...)" (Scherer, 1996: 69).
}

Outros aspectos desse processo podem ser considerados quando se trata de perceber quem encomendou fotografias e em função de quais acontecimentos? Ou ainda quem colecionou fotografias e com que objetivos ou por quais motivações? E em que sentido as imagens (antigas ou atuais) circulam (porque e de quem para quem e/ou de onde para onde), desde sua produção até sua distribuição e posição atual? E em que medida, enfim, a tendência à digitalização progressiva altera tais ou quais elementos do processo referido?

Enfim, o trabalho de pesquisa com imagens já existentes implica, portanto, na busca de outros modos de olhar para estas mesmas imagens, o que pode incluir a produção de novas imagens e de um conhecimento propriamente fotográfico. Isto pode resultar na elaboração de produtos visuais-verbais (no sentido já mencionado de exercício de uma linguagem que pode ser traduzida em diferentes formatos) que possam expressar os sentidos da pesquisa imagética realizada.

Embora as pesquisas aqui apresentadas estejam em grande parte inconclusas, o que limita, evidentemente, o alcance das proposições enunciadas, este artigo terá cumprido seu papel se puder contribuir para chamar a atenção à importância da pesquisa fotográfica no campo da antropologia visual, bem como à necessidade de preservação dos artefatos fotográficos produzidos no passado, ao longo do século XX. Espera-se, 
ainda, que fotógrafos, colecionadores e outros interessados das duas cidades referidas (e de outras) possam ter neste trabalho uma fonte de motivação.

“(...) A imagem, tornada meio de escrita ubíqua, não deve nunca mais ser vista
como natural, distraidamente vista, mas deve ser a partir de agora atenciosamente
lida, analisada, comparada ao seu contexto, como aprendemos a fazê-lo no campo
da informaçâo escrita."
Philippe Quéau, "O tempo do virtual”

\section{Referências}

ACHUTTI, L. E. R., HASSEN, M. N. A. "Caderno de campo digital: antropologia em novas mídias". In: Horizontes Antropológicos, ano 10, n⿳ 21, jan./jun. 2004. Porto Alegre: PPGAS/IFCH/UFRGS, 2004. p. 273-289.

BANKS, M. Dados visuais para pesquisa qualitativa. Porto Alegre: Artmed, 2009. . "Visual research methods". In: Social research, no 11. Surrey (England):

University of Surrey, 1995. p. 1-6. Disponível em <http://www.soc.surrey.ac.uk/sru/SRU11/SRU11.html>. Acesso em: 29mar1999.

BATESON, G. e MEAD, M. Balinese Character. A Photographic Analysis. New York: Special Publications of New York Academy of Sciences, vol. 2, 1942.

CLARK, F. P. de M.. "Reminiscências", 1938 (texto de cunho memorial datilografado em 35 ps.) [S.1.: s.n.].

COLLIER Jr., John. Antropologia Visual: a fotografia como método de pesquisa. São Paulo: EPU-EdUSP, 1973.

ECKERT, C. e ROCHA, A. L. C. "Imagem recolocada: pensar a imagem como instrumento de pesquisa e análise do pensamento coletivo". In: Revista Iluminuras, $\mathrm{n}^{\circ}$. 3. Porto Alegre: BIEV/ UFRGS, 2001. Disponível em: <http://www.iluminuras.ufrgs.br>. Acesso em: 23abr2009.

"Antropologia nas interfaces no mundo do hipertexto". In: Cadernos de Antropologia e Imagem, $\mathrm{n}^{\circ}$. 22(1). Rio de Janeiro: Contra-Capa, 2006. p. 27-44.

FIGUEIREDO Jr., P. M. de. Fotografia e desenvolvimento social: um recorte da realidade. Campina Grande: EDUEP, 2005.

FRANCO, C. H. Percorrendo os meandros da arquitetura: descobrindo a importância da preservação histórica. Taubaté: Trabalho de Graduação Interdisciplinar (UNITAU), 1991.

GONÇALVES, J. R. S.. "Coleções, museus e teorias antropológicas: reflexões sobre conhecimento etnográfico e visualidade". In: Cadernos de Antropologia e Imagem, $\mathrm{n}^{\mathrm{o}}$. 8(1). Rio de Janeiro: NAI/UERJ, 1999. p. 21-34.

KOSSOY, B. Fotografia e História, (2a ed. rev.). São Paulo: Ateliê Editorial, 2001.

Dicionário histórico-fotográfico brasileiro: fotógrafos e ofício da fotografia no Brasil (1833-1910). São Paulo: Instituto Moreira Sales, 2002.

LEITE, M. M. Retratos de família: leitura da fotografia histórica. São Paulo: FAPESP/EDUSP, 1993.

"Negros e fotografia". In: Cadernos de Antropologia e Imagem, $\mathrm{n}^{\circ} .2$. Rio de Janeiro: NAI/UERJ, 1996. p. 145-149.

LIRA, B. de S. Fotografia na Paraíba: um inventário dos fotógrafos através do retrato (1850 a 1950). João Pessoa: SEC/Editora Universitária, 1997. 
MENDONÇA, João Martinho de. Pensando a visualidade no campo da antropologia: reflexões e usos da imagem na obra de Margaret Mead. Campinas: Tese de Doutoramento (IA-Unicamp), 2005.

OTTONI, F. (Ed.). Memória fotográfica de Caldas-MG e fragmentos de história. Poços de Caldas: SIMCO, 2009.

PANET, A. et al. Rio Tinto: estrutura urbana, trabalho e cotidiano. João Pessoa: UNIPÊ, 2002.

PIMENTA, R. de O. O povoamento do planalto da Pedra Branca: Caldas e região. Indaiatuba: Rumograf, 1998.

QUÉAU, P. “O tempo do virtual”. In: PARENTE, A. (Org.) Imagem-máquina: a era das tecnologias do virtual. Rio de Janeiro: Ed. 34, 1993. p. 91-99.

SAMAIN, Etienne. "Balinese Character (re)visitado: uma introdução à obra visual de Gregory Bateson e Margaret Mead". In: ALVES, André. Os Argonautas do Mangue. Campinas: Unicamp/ Imprensa Oficial, 2004. p. 15-72.

SCHERER, Joanna. "Documento fotográfico: fotografias como dado primário na pesquisa antropológica". In: Cadernos de Antropologia e Imagem, $\mathrm{n}^{\circ}$. 3. Rio de Janeiro: NAI/UERJ, 1996. p. 69-83.

SIMSON, O. R. de M. Carnaval em branco e negro: carnaval popular paulistano: 1914-1988. Campinas: Unicamp; São Paulo: Edusp/ Imprensa Oficial, 2007. 